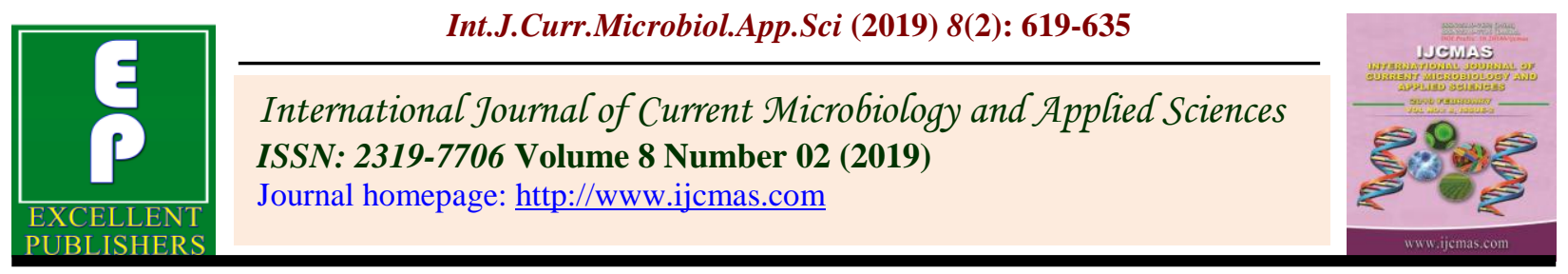

Original Research Article

https://doi.org/10.20546/ijcmas.2019.802.071

\title{
Influence of Date of Sowing and Foliar Application of Nutrients on Dry Matter Production, Partitioning and Growth Parameters of Soybean
}

\author{
G.M. Sumalatha ${ }^{1}$ and D.S. Uppar ${ }^{2 *}$ \\ Department of Seed Science and Technology, College of Agriculture, Dharwad, \\ University of Agricultural Sciences, Dharwad, India \\ *Corresponding author
}

\section{Keywords}

Date of sowing, Nutrient spray, Dry matter partitioning, Crop growth rate and leaf area duration

Article Info

Accepted:

07 January 2019

Available Online:

10 February 2019

\section{A B S T R A C T}

A field experiment on effect of planting date and foliar application of nutrients on crop growth and seed yield of soybean variety DSb 21, was conducted by following split plot design with three replications in Main Agricultural Research Station, UAS, Dharwad during kharif, 2016 and 2017. The experiment consisted of three sowing dates with fortnight interval (first fortnight of June, second fortnight of June and first fortnight of July) and foliar spray of eight treatments. Among the dates of sowing, first fortnight of June $\left(D_{1}\right)$ recorded significantly higher stem $(9.86 \mathrm{~g} / \mathrm{plant})$, leaf $(7.91 \mathrm{~g} / \mathrm{plant})$ and pod $(2.78 \mathrm{~g} / \mathrm{plant})$ at $60 \mathrm{DAS}$, highest total dry matter produced at $30,60 \mathrm{DAS}(5 \mathrm{~g} / \mathrm{plant}$ and $20.55 \mathrm{~g} /$ plant) and harvest $\left(33.83 \mathrm{~g} /\right.$ plant), crop growth rate $\left(17.23 \mathrm{~g} / \mathrm{m}^{2}\right.$ day $\left.{ }^{1}\right)$ and leaf area duration (62.06 days) at 60-75 days after sowing. Foliar spray of $\mathrm{KNO}_{3} @ 0.5 \%+$ $\mathrm{KH}_{2} \mathrm{PO}_{4} @ 0.5 \%+$ Boron $0.50 \%\left(\mathrm{~T}_{8}\right)$ recorded higher stem weight $(10.63 \mathrm{~g})$, leaf $(8.27$ g) and pod (3.11 g) at 60 DAS, highest total dry matter produced at 60 DAS $(22.02 \mathrm{~g})$, crop growth rate $\left(17.38 \mathrm{~g} / \mathrm{m}^{2}\right.$ day $\left.^{1}\right)$ and leaf area duration (60.23 days) at 60-75 days after sowing. Interaction effect of crop sown on first fortnight of June $\left(\mathrm{D}_{1}\right)$ sprayed with $\mathrm{KNO}_{3}$ @ $0.5 \%+\mathrm{KH}_{2} \mathrm{PO}_{4}$ @ $0.5 \%+$ Boron $0.50 \%\left(\mathrm{~T}_{8}\right)$ recorded highest stem $(11.16 \mathrm{~g})$, leaf $(8.69 \mathrm{~g})$ and pod $(3.26 \mathrm{~g})$ at 60 DAS, highest total dry matter produced at 60 DAS $(22.02 \mathrm{~g})$, crop growth rate $\left(17.38 \mathrm{~g} / \mathrm{m}^{2} \mathrm{day}^{1}\right)$ and leaf area duration (68.12days) at $60-75$ days after sowing based on pooled analysis. In general, the results of this study indicated that planting date of first fortnight of June sprayed with $\mathrm{KNO}_{3} @ 0.5 \%+\mathrm{KH}_{2} \mathrm{PO}_{4} @ 0.5 \%+$ Boron $0.50 \%$ were suitable for soybean planting in the Dharwad region of Karnataka.

\section{Introduction}

Soybean [Glycine max (L.) Merrill] crop is emerged as a miracle crop of 20th century because it is versatile and fascinating crop. Apart from high yielding potential (30-35 $\mathrm{q} / \mathrm{ha})$, soybean is very rich in protein $(40 \%)$ and edible oil (20\%) contains a fairly high amount of unsaturated fatty acids and about 1.5 to 3.1 per cent lecithin which is essential for building up of nerve tissue. Soybean is the single largest oilseed produced in the world and it alone contributes about 58 per cent of the global oil seed production. It ranks first in oil seed production followed by rapeseed (13 $\%)$, groundnut $(8 \%)$ and sunflower $(7 \%)$. 
Globally, soybean occupies an area of 126.6 $\mathrm{m}$ ha producing $346.3 \mathrm{mt}$ with the productivity of $2735 \mathrm{~kg}$ per ha. In India soybean occupies an area of $10.60 \mathrm{~m}$ ha producing 12.22 m.t with productivity of $1153 \mathrm{~kg}$ per ha and Karnataka with an area of $0.27 \mathrm{~m}$ ha producing 0.17 m.t with productivity of $639 \mathrm{~kg}$ per ha (Anon., 2017).

In agriculture, climatic factors like temperature, precipitation or rain, snow fall, wind, wind storms, flooding etc are dominent factors to affect crop yields which vary widely throughout the year and place. (Alexandrov and Hoogenboom, 2001). Sowing prior to or later than the optimal sowing date can greatly reduce soybean yield and quality since photo periodism controls not only the number of days to flowering, but also the amount of time available for vegetative plant growth and development. Soybeans sown prior or late to optimum range often lose yield from poor emergence due to inadequate soil temperature or, when planted after the optimal range, from failure to fully develop (Bastidas et al., 2008).

Plant nutrition plays an important role for enhancing seed yield and quality in soybean. Foliar application of nutrients was more beneficial than soil application, since application rates are lesser as compared to soil application (Zayed et al., 2011). Recently, new generation fertilizers have been introduced exclusively for foliar feeding and fertilization. These fertilizers are better source for foliar application (Vibhute, 1998). These fertilizers have different ratios of $\mathrm{N}, \mathrm{P}$ and $\mathrm{K}$ which are highly water soluble and so amenable for foliar nutrition (Jayabal et al., 1999). Quality seed production in soybean is holistic approach which involves the activities like standardization of appropriate season, time of planting and other several techniques to enhance the storability. Keeping all these aspects in view, the present investigation was undertaken.

\section{Materials and Methods}

The Field experiment was conducted during kharif season of 2016 and 2017 in MARS, University of agricultural Sciences, Dharwad. The experiment was laid out in split plot design and comprised of three date of sowing $\left(D_{1}: 1^{\text {st }}\right.$ fortnight of June, $D_{2}: 2^{\text {nd }}$ fortnight of June and $D_{3}: 1^{\text {st }}$ fortnight of July) as main plots and foliar spray were also considered as sub- plot $\left(\mathrm{T}_{1}\right.$ : Water spray, $\mathrm{T}_{2}$ : Urea spray @ $2 \%, \mathrm{~T}_{3}$ : Diammonium phosphate (DAP) @ 2 $\%, \mathrm{~T}_{4}$ : Potassium phosphate $\left(\mathrm{KH}_{2} \mathrm{PO}_{4}\right) @ 1$ $\%, \mathrm{~T}_{5}$ : Boron@ 0.50\%, T : 19:19:19@3\% + Boron@ @ $0.50 \%, \mathrm{~T}_{7}: \mathrm{KNO}_{3} @ 1 \%+$ $\mathrm{KH}_{2} \mathrm{PO}_{4} @ 0.5 \%$ and $\mathrm{T}_{8}: \mathrm{KNO}_{3} @ 0.5 \%+$ $\mathrm{KH}_{2} \mathrm{PO}_{4} @ 0.5 \%+$ Boron $0.50 \%$ ) sprayed at 45 days after sowing for soybean $c v$ DSb 21. Crop cultivation aspects like land preparation, fertilizer, and weed control were followed as recommended for local area. All the plant protection measures were adopted to make the crop free from pests and diseases. The data were recorded on five randomly selected plants of each replication for plant height, number of branches, leaf area, chlorophyll content and seed yield was also recorded. The fortnight meteorological observations during crop growth period are presented in Figure 1.

\section{Results and Discussion}

The dry matter partitioning (g plant ${ }^{-1}$ ) at 30 and 60 days after sowing(DAS) and at harvest as influenced by date of sowing and foliar application of nutrients and their interaction effects during 2016, 2017 and pooled data are presented in the Table 1 and 2.

The leaf and stem dry weight differed significantly due to different date of sowing at 30 DAS. Significantly higher leaf $(2.56,2.50$ and $2.53 \mathrm{~g}$ ) and stem (2.51, 2.44 and $2.47 \mathrm{~g}$ ) weight was recorded in $\mathrm{D}_{1}$ (First fortnight of June) followed by $\mathrm{D}_{2}$ recorded leaf dry weight (1.97, 1.93 and $1.95 \mathrm{~g})$ and stem $(0.55,1.96$ 
and $1.93 \mathrm{~g}$ ) and lowest leaf (1.48, 1.43 and $1.45 \mathrm{~g})$ and stem $(1.47,1.44$ and $1.45 \mathrm{~g})$ dry weight was recorded in $\mathrm{D}_{3}$ (First fortnight of July) during 2016, 2017 and pooled data respectively.

The leaf, stem and pod dry weight differed significantly due to different date of sowing at 60 DAS. Significantly higher leaf $(8.10,7.72$ and $7.91 \mathrm{~g})$, stem $(10.14,9.59$ and $9.86 \mathrm{~g})$ and pod $(2.89,2.67$ and $2.78 \mathrm{~g})$ weight was recorded in $\mathrm{D}_{1}$ (First fortnight of June) followed by $\mathrm{D}_{2}$ (Second fortnight of June) recorded leaf dry weight (7.56, 7.20 and 7.38 g), stem (9.46, 8.95 and $9.21 \mathrm{~g})$ and pod $(2.69,2.49$ and $2.59 \mathrm{~g})$. The lowest leaf $(7.48$, 7.13 and $7.31 \mathrm{~g})$, stem $(9.37,8.86$ and $9.11 \mathrm{~g})$ and pod (2.67, 2.47 and $2.57 \mathrm{~g}$ ) dry weight was recorded in $\mathrm{D}_{3}$ (First fortnight of July) during 2016, 2017 and pooled data respectively.

The stem and pod dry weight differed significantly due to different date of sowing at harvest (Table 3). Significantly higher stem (12.26, 11.74 and $12.00 \mathrm{~g})$ and pod (22.45 and $21.21 \mathrm{~g}$ and $21.83 \mathrm{~g}$ ) weight was recorded in $\mathrm{D}_{1}$ (First fortnight of June) followed by $\mathrm{D}_{2}$ (Second fortnight of June) which recorded dry weight of stem $(11.45,10.95$ and $11.20 \mathrm{~g})$ and pod $(20.48,19.38$ and $19.93 \mathrm{~g})$. The lowest stem $(11.33,10.84$ and $11.09 \mathrm{~g})$ and pod (19.82, 18.61 and $19.22 \mathrm{~g})$ dry weight was recorded in $\mathrm{D}_{3}$ (First fortnight of July) during 2016, 2017 and pooled data respectively.

The $\mathrm{D}_{1}$ (First fortnight of June) recorded higher leaf dry weight at $30(2.53 \mathrm{~g})$ and 60 DAS (7.91 g) as compared to $\mathrm{D}_{2}$ (Second fortnight of June) and $\mathrm{D}_{3}$ (First fortnight of July) based on pooled data. This may be due to more number of branches, leaves and increased height due to the prevalence of favorable environment during first 60 DAS in the first date of sowing. Park et al., (1987) were also of the same opinion with regard to leaf dry weight due to delayed sowing in soybean.

The stem dry weight varied significantly during 30 DAS (2.47 g), 60 DAS (9.86 g) and at harvest $(12.00 \mathrm{~g})$, it was more in $\mathrm{D}_{1}$ (first fortnight of June) compared to $\mathrm{D}_{2}$ (Second fortnight of June) and $\mathrm{D}_{3}$ (First fortnight of July), thus indicating the impact of higher maximum temperature on the reduction of stem dry weight in the second and third sowing. Dhingra et al., (1995) also stated that the total dry matter yield and its partitioning to different components were also drastically reduced with each delay in sowing.

The dry weight of the pods increased continuously throughout the crop growing in all the dates of sowing. The dry weight of the pods was significantly higher in $\mathrm{D}_{1}$ (First fortnight of June) at 60 DAS (2.78 g) and at harvest $\left(21.21 \mathrm{~g}\right.$ ) compared to $\mathrm{D}_{2}$ (Second fortnight of June) and $\mathrm{D}_{3}$ (First fortnight of July) due to higher number of pods. Increase in seed yield may be attributed to more number of pods in the normal sowing date as compared to delayed sowing. Similar results were also reported by Potdar and Asmatoddin (1991) in soybean.

The effect due to the foliar application of nutrients was found non significant on dry matter partitioning at 30 DAS. However, maximum dry weight of leaf $(2.44,2.39$ and $2.42 \mathrm{~g})$ and shoot $(2.42,2.32$ and $2.37 \mathrm{~g}$ ) was recorded in $\mathrm{T}_{6}$ and lowest dry weight of leaf (1.70, 1.60 and $1.65 \mathrm{~g})$ was recorded in $\mathrm{T}_{3}$ and stem $(1.74,1.71$ and $1.73 \mathrm{~g})$ in $\mathrm{T}_{2}$ during 2016, 2017 and pooled data respectively. The dry matter partitioning of leaf, stem and pod differed significantly due to foliar application of nutrients at 60 DAS. Significantly higher leaf dry weight $(8.34,8.23$ and $8.29 \mathrm{~g})$ was recorded inT 6 (19:19:19 NPK @ $3 \%+$ Boron @ $0.50 \%)$, stem $(10.85,10.41$ and $10.63 \mathrm{~g})$ in $\mathrm{T}_{8}\left(\mathrm{KNO}_{3} @ 0.5 \%+\mathrm{KH}_{2} \mathrm{PO}_{4} @ 0.5 \%+\right.$ 
Boron $0.50 \%)$ and pod (3.12, 3.10 and 3.11 g) was on par with $\mathrm{T}_{6}, \mathrm{~T}_{7}$ and $\mathrm{T}_{8}$ and lower leaf $(5.41,5.33$ and $5.37 \mathrm{~g})$, stem $(7.35,6.97$ and $7.16 \mathrm{~g}$ ) and pod (2.20, 1.92 and $2.06 \mathrm{~g})$ dry weight was recorded in control during 2016, 2017 and pooled data respectively.

The dry matter partitioning of stem and pod differed significantly due to foliar application of nutrients at harvest. Significantly higher stem $(12.58,12.50$ and $12.54 \mathrm{~g}$ ) and pod $(21.89,20.85$ and $21.37 \mathrm{~g})$ weight was recorded in $\mathrm{T}_{8}\left(\mathrm{KNO}_{3} @ 0.5 \%+\mathrm{KH}_{2} \mathrm{PO}_{4} @\right.$ $0.5 \%+$ Boron $0.50 \%$ ) which is on par for pod dry weight $(21.90,20.84$ and $21.37 \mathrm{~g}$ ) with $\mathrm{T}_{6}$ (19:19:19 NPK @ $3 \%+$ Boron @ $0.50 \%)$ which recorded stem weight (12.57, 12.50 and $12.54 \mathrm{~g})$ and $\mathrm{T}_{7}\left(\mathrm{KNO}_{3} @ 1 \%+\right.$ $\left.\mathrm{KH}_{2} \mathrm{PO}_{4} @ 0.5 \%\right)$ stem $(12.56,12.49$ and $12.52 \mathrm{~g})$ weight and lowest stem $(10.31,9.25$ and $9.78 \mathrm{~g}$ ) and pod (19.56, 18.01 and 18.83 g) dry weight was recorded in control during 2016, 2017 and pooled data respectively. Significant enhancement in leaf dry matter was observed due to foliar spray after 45 days after sowing. Even though there was a decline in leaf dry matter after 60 DAS. The plants which received foliar spray of potassium nitrate $(0.5 \%)+$ potassium dihydrogen phosphate $(0.5 \%)+$ Boron $(0.50 \%)$ maintained highest leaf dry matter at 60 DAS $(8.29 \mathrm{~g})$. The increased leaf dry matter might be due to the supply of nutrients at the hour of need enabling the plants to maintain higher chlorophyll content, leaf area per plant, leaf area index and decrease in the rate of senescence (Zayed et al., 2011).

The increase in stem dry matter in the $T_{8}$ treatment at $60 \mathrm{DAS}(10.63 \mathrm{~g})$ and at harvest $(12.54 \mathrm{~g})$. It might be due to the role of potassium in improving water use efficiency in potassium nitrate and potassium dihydrogen phosphate, boron in translocating the photosynthates. Similar results were reported by Thalooth et al., (2006) in mungbean. The pod dry matter increases gradually from 45 DAS to harvest irrespective of treatments. Higher pod dry weight was recorded in $\mathrm{T}_{8}$ i.e., combination of $\mathrm{KNO}_{3}(0.5$ $\%)+\mathrm{KH}_{2} \mathrm{PO}_{4}(0.5 \%)+$ Boron $(0.50 \%)$ at 60 DAS $(2.78 \mathrm{~g})$ and at harvest $(21.37 \mathrm{~g})$. This might be due to the role of boron in translocation of photosynthates to the economic parts. The results are in agreement with those reported by Thalooth et al., (2006) in mung bean and Vekaria et al., (2013) in green gram.

T6 (19:19:19 NPK @ 3\%+Boron@ 0.50\%) also recorded higher total dry matter at 60 DAS $(22.02 \mathrm{~g})$ and at harvest $(33.90 \mathrm{~g})$ compared to control which recorded lowest total dry matter at 60 DAS (14.59 g) and at harvest $(28.61 \mathrm{~g})$ based on pooled data. Increased dry mater production in leaf, stem, reproductive parts and total dry matter at harvest was mainly due to additional foliar application of water soluble fertilizer which might have led to increased uptake of nutrients which in turn helped in increased plant height, number of branches, leaf area and leaf area index (LAI). This might have contributed for better plant growth and ultimately increased the dry matter production. These results are in conformation with the findings of Anbumani et al., (2003) who reported that application of foliar nutrients facilitated more availability and less interference in the absorption of nutrients. This paves the way for the production of more biomass leading to higher dry matter production and adequate supply of $\mathrm{N}, \mathrm{P}$ and $\mathrm{K}$ through foliar application. These results are in conformity with the results of Rajesh (2011), Reddy et al., (2004).

\section{Total dry matter accumulation}

The total dry matter partitioning $\left(\mathrm{g} \mathrm{plant}^{-1}\right)$ at 30, 60 (DAS) and at harvest as influenced by date of sowing and foliar application of 
nutrients and their interaction effects during 2016, 2017 and pooled data are presented in the Table 4.

The total dry matter differed significantly due to varied date of sowing. Significantly highest total dry matter (5.07, 4.94 and $5.00 \mathrm{~g}$ ), $(21.12,19.98$ and $20.55 \mathrm{~g})$ and $(34.72,32.95$ and $33.83 \mathrm{~g}$ ) was recorded in $\mathrm{D}_{1}$ (First fortnight of June) followed by $\mathrm{D}_{2}$ (3.94, 3.85 and $3.90 \mathrm{~g}),(19.72,18.65$ and $19.18 \mathrm{~g})$ and (31.92, 30.33 and $31.13 \mathrm{~g})$ and lowest dry matter $(2.95,2.87$ and $2.91 \mathrm{~g}),(19.52,18.46$ and $18.99 \mathrm{~g})$ and $(31.15,29.45$ and $30.30 \mathrm{~g})$ was recorded in $\mathrm{D}_{3}$ (First fortnight of July) at 30, 60 and at harvest respectively, during 2016, 2017 and pooled data respectively.

This might be due to conducive optimum temperature which has favored sufficient growing period for vegetative and reproductive stages in early sowing. Longer period of growth had resulted in maximum dry matter in the vegetative as well as the reproductive periods have further resulted in the highest pod and seed weight. The sowing time has pronounced effects on growth and yield of most crops as delay in sowing beyond the optimum time usually results in yield reduction. The results are in conformity with Neenu et al., (2017) stated that, late sowing affected the plant stature resulting in premature flowering before the plant could attain its full size. The crop sown under late planting conditions could not accumulate sufficient dry matter because of lesser vegetative growth and reproductive period due to shorter day length. The total dry matter differed non significantly due to foliar application of nutrients at 30 DAS. However, numerically highest total dry matter (4.86, 4.72 and $4.79 \mathrm{~g})$ was recorded in $\mathrm{T}_{6}(19: 19: 19$ NPK@3\% + Boron @ 0.50\%) and lowest was recorded in control $(3.58,3.46$ and 3.52 g) during 2016, 2017 and pooled data, respectively.
The total dry matter differed significantly due to foliar application of nutrients at $60 \mathrm{DAS}$ and at harvest as presented in the Table 4 . Significantly higher total dry matter (22.30, 21.73 and $22.02 \mathrm{~g})$ and $(34.47,33.35$ and $33.91 \mathrm{~g}$ ) was recorded in $\mathrm{T}_{8}$ and it was on par with $\mathrm{T}_{6}(22.30,21.73$ and $22.02 \mathrm{~g})$ and (34.46, 33.34 and $33.90 \mathrm{~g})$ and $\mathrm{T}_{7}(22.28,21.73$ and $22.00 \mathrm{~g})$ and $(34.45,33.33$ and $33.89 \mathrm{~g})$ and lower total dry matter (14.96, 14.22 and 14.53 g) and $(29.87,27.35$ and $28.61 \mathrm{~g})$ was recorded in control during 2016, 2017 and pooled data respectively at 60 and harvest respectively. This might be due to the role of boron in cell division, cell differentiation, development, calcium utilization, translocation of photosynthates and growth regulators from source to sink, thus helping in maintaining higher leaf area, leaf area index and higher number of pods and pod weight per plant (Kalyani et al., 1993). Similar results were reported by Hemantaranjan et al., (2000) in soybean, Mahmoud et al., (2006) in fababean and Pradeep and Elamathi (2007) in greengram.

Interaction effect due to date of sowing and foliar application of nutrients differed non significantly for dry matter partioning at 30, 60 and harvest.

\section{Crop growth rate}

The crop growth rate (CGR, $\left.\mathrm{gm}^{-2} \mathrm{day}^{-1}\right)$ at 30 45 DAS, 45-60 DAS, 60-75 DAS and 75 DAS to harvest as influenced by date of sowing and foliar application of nutrients and their interaction effects during 2016, 2017 and pooled data are presented in the Table 5.

The crop growth rate differed significantly due to different date of sowing. Significantly higher crop growth rate (30-45 DAS:12.61, 12.60 and $12.61 \mathrm{gm}^{-2} \mathrm{day}^{-1}, 45-60$ DAS: 29.04, 27.30 and $28.17 \mathrm{gm}^{-2} \mathrm{day}^{-1}, 60-75$ DAS: 17.30, 17.16 and $1723 \mathrm{gm}^{-2}$ day $^{-1}$ and 
75 DAS-harvest: $14.40,13.50$ and $13.39 \mathrm{gm}^{-2}$ day $^{-1}$ ) was recorded in $D_{1}$ (First fortnight of June) followed by $\mathrm{D}_{2}$ (30-45 DAS:11.97, 11.96 and $11.97 \mathrm{gm}^{-2}$ day $^{-1}$, 45-60 DAS: 26.80, 24.01 and $25.41 \mathrm{gm}^{-2} \mathrm{day}^{-1}, 60-75$ DAS: $16.13,15.98$ and $16.06 \mathrm{gm}^{-2}$ day $^{-1}$ and 75 DAS - harvest: $13.11,12.34$ and 12.73 $\mathrm{gm}^{-2}$ day $^{-1}$ ) and lowest crop growth rate (3045 DAS: $11.92,11.91$ and $11.92 \mathrm{gm}^{-2}$ day $^{-1}$, 45-60 DAS: $23.25,21.15$ and $22.20 \mathrm{gm}^{-2}$ day 1 , 60-75 DAS:14.99, 14.61 and $14.80 \mathrm{gm}^{-2}$ day $^{-1}$ and 75 DAS to harvest: $11.22,10.75$ and $10.99 \mathrm{gm}^{-2}$ day $^{-1}$ ) was recorded in $\mathrm{D}_{3}$ (First fortnight of July) during 2016, 2017 and pooled data respectively. This might be due to availability of sufficient period for vegetative and reproductive growth which resulted in higher crop growth rate. Similar results were reported by Daroish et al., (2005), Kandil et al., (2013) and Ebrahimi et al., (2012).

The effect due to the foliar application of nutrients on crop growth rate was found nonsignificant at 30-45 days after sowing. However, $T_{6}$ (19:19:19 NPK @ $3 \%+$ Boron @ $0.50 \%$ ) recorded highest crop growth rate (12.39, 12.38 and $\left.12.38 \mathrm{gm}^{-2} \mathrm{day}^{-1}\right)$ and lowest (11.36, 11.34 and $11.35 \mathrm{gm}^{-2}$ day $^{-1}$ ) was recorded inurea spray (2\%) during 2016, 2017 and pooled data respectively.

The effect due to the foliar application of nutrients on crop growth rate was significantly differed at 45-60 DAS. Among that, $\mathrm{T}_{8}\left(\mathrm{KNO}_{3} @ 0.5 \%+\mathrm{KH}_{2} \mathrm{PO}_{4} @ 0.5 \%+\right.$ Boron $0.50 \%$ ) noticed significantly highest crop growth rate $\left(27.86,25.53\right.$ and $26.70 \mathrm{gm}^{-2}$ day $^{-1}$ ) which is on par with $\mathrm{T}_{6}(27.04,25.52$ and $\left.26.28 \mathrm{gm}^{-2} \mathrm{day}^{-1}\right)$ and $\mathrm{T}_{7}(27.85,25.52$ and $26.69 \mathrm{gm}^{-2}$ day). The lowest crop growth rate $\left(24.44,22.23\right.$ and $23.34 \mathrm{gm}^{-2}$ day $^{-1}$ ) was recorded in control during 2016, 2017 and pooled data respectively.

The effect due to the foliar application of nutrients on crop growth rate was significantly differed at 60-75 DAS. Among that, $\mathrm{T}_{8}\left(\mathrm{KNO}_{3} @ 0.5 \%+\mathrm{KH}_{2} \mathrm{PO}_{4} @ 0.5 \%+\right.$ Boron $0.50 \%$ ) recorded significantly highest crop growth rate $\left(17.41,17.35\right.$ and $17.38 \mathrm{gm}^{-}$ ${ }^{2}$ day $\left.^{-1}\right)$ which is on par $(17.40,17.34$ and $17.37 \mathrm{gm}^{-2}$ day $^{-1}$ )with $\mathrm{T}_{6}$ (19:19:19 NPK @ 3 \%+Boron@0.50\%)and $\mathrm{T}_{7}\left(\mathrm{KNO}_{3} @ 1 \%+\right.$ $\left.\mathrm{KH}_{2} \mathrm{PO}_{4} @ 0.5 \%\right)$. The lowest crop growth rate $\left(14.54,14.08\right.$ and $14.31 \mathrm{gm}^{-2}$ day) was recorded in control during 2016, 2017 and pooled data respectively.

The effect due to the foliar application of nutrients on crop growth rate was significantly differed at 75 days after sowing to harvest. Among that, $\mathrm{T}_{8}\left(\mathrm{KNO}_{3} @ 0.5 \%+\right.$ $\mathrm{KH}_{2} \mathrm{PO}_{4} @ 0.5 \%+$ Boron $0.50 \%$ ) recorded significantly highest crop growth rate (14.13, 13.21 and $13.67 \mathrm{gm}^{-2}$ day $^{-1}$ ) which is on par (14.12, 13.20 and $13.66 \mathrm{gm}^{-2}$ day $^{-1}$ ) with $\mathrm{T}_{6}$ (19:19:19 NPK@3\%+Boron@0.50\%) and $\mathrm{T}_{7}\left(\mathrm{KNO}_{3} @ 1 \%+\mathrm{KH}_{2} \mathrm{PO}_{4} @ 0.5 \%\right)$. The lowest crop growth rate (11.23, 10.60 and $10.92 \mathrm{gm}^{-2}$ day $^{-1}$ ) was recorded in control during 2016, 2017 and pooled data respectively.

The crop growth rate showed non significant differences due to interaction of date of sowing and foliar application of nutrients at all stages of observation.

\section{Leaf area duration}

The leaf area duration (LAD, days) at 30-45 days after sowing, 45-60 days after sowing, 60-75 days after sowing (DAS) as influenced by date of sowing and foliar application of nutrients and their interaction effects during 2016, 2017 and pooled data are presented in the Table 6.

The leaf area duration differed significantly due to different date of sowing. Significantly higher leaf area duration (30-45 DAS: 36.89, 36.27 and 36.58, 45-60 DAS:66.54, 66.03 and 
66.28,60-75 DAS:62.85, 61.28 and 62.06)

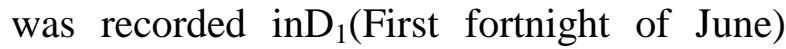
followed by $\mathrm{D}_{2}$ (30-45 DAS:32.93, 32.40 and 32.67, 45-60 DAS:62.56, 62.06 and 62.31, 60-75 DAS:58.20, 57.76 and 57.98) and lowest leaf area duration (30-45 DAS:29.38, 29.23 and 29.31, 45-60 DAS:59.39, 58.47 and 58.93, 60-75 DAS:55.95, 54.83 and 55.39) was recorded $\mathrm{inD}_{3}$ (First fortnight of July) during 2016, 2017 and pooled data respectively. This might be due to more availability of growing period for vegetative and reproductive stages. The results of the present investigation are in line with the findings of Aastha and Janardan (2016).

The effect due to the foliar application of nutrients leaf area duration was found nonsignificant at 30-45 DAS. However, $\mathrm{T}_{6}$ (19:19:19 NPK@3\%+Boron@0.50\%) recorded highest leaf area duration (32.65, 32.14 and 32.40) and lowest (32.24, 31.93 and 32.08) was recorded $\mathrm{inT}_{2}$ (Urea spray @ 2 \%)during 2016, 2017 and pooled data respectively.

The effect due to the foliar application of nutrients on leaf area duration was significantly differed at 45-60 DAS. Among that, $\mathrm{T}_{8}\left(\mathrm{KNO}_{3} @ 0.5 \%+\mathrm{KH}_{2} \mathrm{PO}_{4} @ 0.5 \%+\right.$ Boron $0.50 \%$ ) noticed significantly highest leaf area duration (64.96, 64.67 and 64.82) which is on par $(64.95,64.66$ and 64.81) with $\mathrm{T}_{6}$ (19:19:19 NPK@3\%+Boron@0.50\%) and $\mathrm{T}_{7}\left(\mathrm{KNO}_{3} @ 1 \%+\mathrm{KH}_{2} \mathrm{PO}_{4} @ 0.5 \%\right)$. The lowest leaf area duration (59.31, 58.08 and 58.70) was recorded in control during 2016, 2017 and pooled data respectively.

The effect due to the foliar application of nutrients on leaf area duration was significantly differed at60-75 days after sowing. Among that, $\mathrm{T}_{8}\left(\mathrm{KNO}_{3} @ 0.5 \%+\right.$ $\mathrm{KH}_{2} \mathrm{PO}_{4} @ 0.5 \%+$ Boron $0.50 \%$ ) noticed significantly highest leaf area duration (60.67, 59.78 and 60.23) which is on par (60.66,
59.77 and 60.22) with $\mathrm{T}_{6}(19: 19: 19$ NPK @ 3 $\%+$ Boron@0.50\%) and $\mathrm{T}_{7}\left(\mathrm{KNO}_{3} @ 1 \%+\right.$ $\left.\mathrm{KH}_{2} \mathrm{PO}_{4} @ 0.5 \%\right)$. The lowest leaf area duration (56.67, 54.78 and 55.72) was recorded in control during 2016, 2017 and pooled data respectively.

Foliar application of $\mathrm{T}_{8}\left(\mathrm{KNO}_{3} @ 0.5 \%+\right.$ $\mathrm{KH}_{2} \mathrm{PO}_{4} @ 0.5 \%+$ Boron $0.50 \%$ ) recorded better crop growth parameters like crop growth rate and leaf area duration at 75 DAS and at all stages of crop growth. This might be due to potassium nitrate provides nitrogen, potassium both influences the water economy and crop growth, through its effect on water uptake, root growth, maintenance of turgour, transpiration and stomatal behavior. This might be due to the fact that those plants were supplied with three nutrients at the required stages which enable them to have higher leaf area, net assimilation rate thus enhancing the crop growth. The decline in crop growth rate after 60 DAS might be due to loss in dry matter on account of senescence. Similar results were reported by Mahobia et al., (2006) in pigeonpea, Heidarian et al., (2011) in soybean and Vekaria et al., (2013) in greengram.

$\mathrm{T}_{6}(19: 19: 19$ NPK @ 3\%+Boron @ 0.50\%) also recorded higher values for crop growth parameters like crop growth rate and leaf area duration compared to control which recorded lowest crop growth parameters like crop growth rate and leaf area duration at 75 DAS and all stages of crop growth. This might be due to the fact that those plants were supplied with the three nutrients at the required stages which enable them to have higher leaf area, net assimilation rate thus enhancing the crop growth. The decline in crop growth after 60 DAS might be due to loss in dry matter on account of senescence Similar results were reported by Kalyani et al.,(1993) in Pigeon pea, Sunil et al., (2010) in mung bean and Mahobia et al., (2006) in Pigeon pea 
Table.1 Effect of date of sowing and foliar application of nutrients on dry matter partitioning of soybean (cv. DSb 21) at 30 DAS

\begin{tabular}{|c|c|c|c|c|c|c|}
\hline \multicolumn{7}{|c|}{ Dry matter partitioning (g/plant) } \\
\hline \multirow[t]{2}{*}{ Treatments } & \multicolumn{3}{|c|}{ Leaf $\left(\right.$ g plant $\left.^{-1}\right)$} & \multicolumn{3}{|c|}{ Stem $\left(g_{\text {plant }}{ }^{-1}\right)$} \\
\hline & 2016 & 2017 & Pooled & 2016 & 2017 & Pooled \\
\hline \multicolumn{7}{|l|}{ Main plot (D) } \\
\hline $\mathbf{D}_{1}$ & 2.56 & 2.50 & 2.53 & 2.51 & 2.44 & 2.47 \\
\hline $\mathbf{D}_{2}$ & 1.97 & 1.93 & 1.95 & 1.96 & 1.93 & 1.95 \\
\hline $\mathbf{D}_{3}$ & 1.48 & 1.43 & 1.45 & 1.47 & 1.44 & 1.45 \\
\hline S. Em. \pm & 0.03 & 0.03 & 0.02 & 0.03 & 0.03 & 0.01 \\
\hline C.D. @ $5 \%$ & 0.13 & 0.13 & 0.05 & 0.10 & 0.10 & 0.04 \\
\hline \multicolumn{7}{|l|}{ Sub Plot $(T)$} \\
\hline$T_{1}$ & 1.80 & 1.74 & 1.77 & 1.78 & 1.71 & 1.75 \\
\hline $\mathbf{T}_{2}$ & 1.71 & 1.65 & 1.68 & 1.74 & 1.71 & 1.73 \\
\hline $\mathbf{T}_{3}$ & 1.70 & 1.60 & 1.65 & 2.03 & 2.00 & 2.01 \\
\hline $\mathbf{T}_{4}$ & 2.05 & 1.95 & 2.00 & 1.84 & 1.85 & 1.85 \\
\hline $\mathbf{T}_{5}$ & 2.03 & 2.00 & 2.01 & 1.92 & 1.82 & 1.87 \\
\hline$T_{6}$ & 2.44 & 2.39 & 2.42 & 2.42 & 2.32 & 2.37 \\
\hline $\mathbf{T}_{7}$ & 1.98 & 1.96 & 1.97 & 1.97 & 1.94 & 1.96 \\
\hline $\mathbf{T}_{8}$ & 2.32 & 2.30 & 2.31 & 2.13 & 2.11 & 2.12 \\
\hline S. Em. \pm & 0.07 & 0.07 & 0.04 & 0.051 & 0.05 & 0.03 \\
\hline C.D. @ $5 \%$ & NS & NS & NS & NS & NS & NS \\
\hline \multicolumn{7}{|l|}{ Interactions $(\mathrm{D} \times \mathrm{T})$} \\
\hline $\mathbf{D}_{1} \mathbf{T}_{\mathbf{I}}$ & 2.63 & 2.50 & 2.57 & 2.51 & 2.42 & 2.47 \\
\hline $\mathbf{D}_{1} \mathbf{T}_{2}$ & 2.41 & 2.35 & 2.38 & 2.12 & 2.09 & 2.11 \\
\hline $\mathbf{D}_{1} \mathbf{T}_{3}$ & 2.21 & 2.11 & 2.16 & 2.65 & 2.60 & 2.63 \\
\hline $\mathbf{D}_{1} \mathbf{T}_{4}$ & 2.58 & 2.48 & 2.53 & 2.44 & 2.45 & 2.45 \\
\hline $\mathbf{D}_{1} \mathbf{T}_{5}$ & 2.45 & 2.39 & 2.42 & 2.65 & 2.43 & 2.54 \\
\hline$D_{1} T_{6}$ & 2.85 & 2.78 & 2.82 & 2.81 & 2.72 & 2.77 \\
\hline $\mathbf{D}_{1} \mathbf{T}_{7}$ & 2.52 & 2.51 & 2.52 & 2.48 & 2.45 & 2.47 \\
\hline $\mathbf{D}_{1} \mathbf{T}_{8}$ & 2.86 & 2.85 & 2.86 & 2.38 & 2.34 & 2.36 \\
\hline $\mathbf{D}_{2} \mathbf{T}_{1}$ & 1.56 & 1.53 & 1.54 & 1.62 & 1.53 & 1.58 \\
\hline $\mathbf{D}_{2} \mathbf{T}_{2}$ & 1.71 & 1.65 & 1.68 & 1.74 & 1.73 & 1.74 \\
\hline $\mathbf{D}_{2} \mathbf{T}_{3}$ & 1.70 & 1.61 & 1.66 & 1.97 & 1.91 & 1.94 \\
\hline $\mathbf{D}_{2} \mathbf{T}_{4}$ & 2.05 & 1.95 & 2.00 & 1.88 & 1.88 & 1.88 \\
\hline $\mathbf{D}_{2} \mathbf{T}_{5}$ & 2.03 & 2.00 & 2.01 & 1.92 & 1.91 & 1.92 \\
\hline $\mathbf{D}_{2} \mathbf{T}_{6}$ & 2.42 & 2.39 & 2.41 & 2.42 & 2.33 & 2.38 \\
\hline $\mathbf{D}_{2} \mathbf{T}_{7}$ & 1.98 & 1.97 & 1.98 & 2.03 & 2.01 & 2.02 \\
\hline $\mathbf{D}_{2} \mathbf{T}_{8}$ & 2.32 & 2.30 & 2.31 & 2.13 & 2.12 & 2.13 \\
\hline $\mathbf{D}_{3} \mathbf{T}_{1}$ & 1.21 & 1.20 & 1.21 & 1.21 & 1.19 & 1.20 \\
\hline$D_{3} T_{2}$ & 1.02 & 0.96 & 0.99 & 1.35 & 1.32 & 1.34 \\
\hline $\mathbf{D}_{3} \mathbf{T}_{3}$ & 1.19 & 1.09 & 1.14 & 1.47 & 1.48 & 1.48 \\
\hline $\mathbf{D}_{3} \mathbf{T}_{4}$ & 1.51 & 1.43 & 1.47 & 1.21 & 1.21 & 1.21 \\
\hline $\mathbf{D}_{3} \mathbf{T}_{5}$ & 1.61 & 1.60 & 1.61 & 1.19 & 1.12 & 1.16 \\
\hline$D_{3} T_{6}$ & 2.05 & 2.01 & 2.03 & 2.02 & 1.92 & 1.97 \\
\hline $\mathbf{D}_{3} \mathbf{T}_{7}$ & 1.43 & 1.41 & 1.42 & 1.41 & 1.37 & 1.39 \\
\hline $\mathbf{D}_{3} \mathbf{T}_{8}$ & 1.79 & 1.75 & 1.77 & 1.89 & 1.88 & 1.89 \\
\hline S. Em. \pm & 0.22 & 0.21 & 0.11 & 0.153 & 0.15 & 0.08 \\
\hline C.D. @ 5 \% & NS & NS & NS & NS & NS & NS \\
\hline
\end{tabular}

$\mathbf{D}_{1}: 1^{\text {st }}$ fortnight of June, $\mathbf{D}_{2}: 2^{\text {nd }}$ fortnight of June, $\mathbf{D}_{3}: 1^{\text {st }}$ fortnight of July

$\mathbf{T}_{1}$ : Water spray, $\mathbf{T}_{2}:$ Urea spray @ $2 \%, \mathbf{T}_{3}:$ DAP @ 2\%, $\mathbf{T}_{4}: \mathrm{KH}_{2} \mathrm{PO}_{4} @ 1 \%, \mathbf{T}_{5}:$ Boron @ 0.5 \%, $\mathbf{T}_{6}:$ 19:19:19 NPK @ $3 \%+\mathrm{Boron} @ 0.5 \%$, $\mathbf{T}_{7}: \mathrm{KNO}_{3} @ 1 \%+\mathrm{KH}_{2} \mathrm{PO}_{4} @ 0.5 \%, \mathbf{T}_{8}: \mathrm{KNO}_{3} @ 0.5 \%+\mathrm{KH}_{2} \mathrm{PO}_{4} @ 0.5 \%+$ Boron $0.5 \%$, NS: Non-significant 
Table.2 Effect of date of sowing and foliar application of nutrients on dry matter partitioning at 60 DAS of soybean (cv. DSb 21)

\begin{tabular}{|c|c|c|c|c|c|c|c|c|c|}
\hline \multicolumn{10}{|c|}{ Dry matter partitioning (g/plant) } \\
\hline Treatments & \multicolumn{3}{|c|}{ Leaf $\left(g_{\text {plant }}{ }^{-1}\right)$} & \multicolumn{3}{|c|}{ Stem $\left(\right.$ g plant $\left.^{-1}\right)$} & \multicolumn{3}{|c|}{ Pod $\left(g_{\text {plant }}{ }^{-1}\right)$} \\
\hline Main plot (D) & 2016 & 2017 & Pooled & 2016 & 2017 & Pooled & 2016 & 2017 & Pooled \\
\hline $\mathrm{D}_{1}$ & 8.10 & 7.72 & 7.91 & 10.14 & 9.59 & 9.86 & 2.89 & 2.67 & 2.78 \\
\hline $\mathbf{D}_{2}$ & 7.56 & 7.20 & 7.38 & 9.46 & 8.95 & 9.21 & 2.69 & 2.49 & 2.59 \\
\hline $\mathbf{D}_{3}$ & 7.48 & 7.13 & 7.31 & 9.37 & 8.86 & 9.11 & 2.67 & 2.47 & 2.57 \\
\hline S. Em. \pm & 0.02 & 0.02 & 0.01 & $\mathbf{0 . 0 3}$ & 0.03 & 0.02 & 0.04 & 0.04 & 0.03 \\
\hline C.D. @ 5\% & 0.10 & 0.09 & 0.04 & 0.12 & 0.12 & 0.05 & 0.17 & 0.15 & 0.09 \\
\hline \multicolumn{10}{|l|}{ Sub Plot $(T)$} \\
\hline$T_{1}$ & 5.41 & 5.33 & 5.37 & 7.35 & 6.97 & 7.16 & 2.20 & 1.92 & 2.06 \\
\hline $\mathbf{T}_{2}$ & 7.91 & 7.25 & 7.58 & 9.23 & 8.54 & 8.89 & 2.51 & 2.12 & 2.31 \\
\hline $\mathbf{T}_{3}$ & 8.15 & 7.51 & 7.83 & 9.71 & 8.98 & 9.35 & 2.72 & 2.32 & 2.52 \\
\hline $\mathbf{T}_{4}$ & 8.26 & 7.56 & 7.91 & 9.92 & 9.05 & 9.48 & 2.84 & 2.49 & 2.67 \\
\hline$T_{5}$ & 6.99 & 6.47 & 6.73 & 8.51 & 8.33 & 8.42 & 2.37 & 2.20 & 2.29 \\
\hline$T_{6}$ & 8.34 & 8.23 & 8.29 & 10.84 & 10.40 & 10.62 & 3.12 & 3.10 & 3.11 \\
\hline $\mathbf{T}_{7}$ & 8.33 & 8.23 & 8.28 & 10.83 & 10.40 & 10.62 & 3.12 & 3.10 & 3.11 \\
\hline $\mathbf{T}_{8}$ & 8.33 & 8.22 & 8.27 & 10.85 & 10.41 & 10.63 & 3.12 & 3.10 & 3.11 \\
\hline S. Em. \pm & 0.07 & 0.07 & 0.04 & 0.09 & 0.09 & 0.04 & 0.07 & 0.06 & 0.05 \\
\hline C.D. @ $5 \%$ & 0.21 & 0.20 & 0.10 & 0.25 & 0.24 & 0.12 & 0.19 & 0.17 & 0.13 \\
\hline \multicolumn{10}{|l|}{ Interactions $(\mathrm{D} \times \mathrm{T})$} \\
\hline $\mathbf{D}_{1} \mathbf{T}_{\mathbf{I}}$ & 5.68 & 5.60 & 5.64 & 7.72 & 7.32 & 7.52 & 2.31 & 2.02 & 2.16 \\
\hline $\mathbf{D}_{1} \mathbf{T}_{2}$ & 8.30 & 7.61 & 7.96 & 9.69 & 8.97 & 9.33 & 2.63 & 2.23 & 2.43 \\
\hline$D_{1} T_{3}$ & 8.56 & 7.89 & 8.22 & 10.20 & 9.43 & 9.81 & 2.85 & 2.44 & 2.65 \\
\hline$D_{1} T_{4}$ & 8.67 & 7.94 & 8.31 & 10.41 & 9.50 & 9.96 & 2.98 & 2.61 & 2.80 \\
\hline$D_{1} T_{5}$ & 7.34 & 6.80 & 7.07 & 8.93 & 8.74 & 8.84 & 2.49 & 2.31 & 2.40 \\
\hline$D_{1} T_{6}$ & 8.76 & 8.64 & 8.70 & 11.38 & 10.92 & 11.15 & 3.27 & 3.25 & 3.26 \\
\hline $\mathbf{D}_{1} \mathbf{T}_{7}$ & 8.74 & 8.64 & 8.69 & 11.37 & 10.92 & 11.15 & 3.27 & 3.25 & 3.26 \\
\hline$D_{1} T_{8}$ & 8.74 & 8.63 & 8.69 & 11.39 & 10.93 & 11.16 & 3.27 & 3.25 & 3.26 \\
\hline $\mathbf{D}_{2} \mathbf{T}_{1}$ & 5.30 & 5.22 & 5.26 & 7.20 & 6.83 & 7.02 & 2.16 & 1.88 & 2.02 \\
\hline $\mathbf{D}_{2} \mathbf{T}_{2}$ & 7.75 & 7.10 & 7.43 & 9.04 & 8.37 & 8.71 & 2.46 & 2.08 & 2.27 \\
\hline $\mathbf{D}_{2} \mathbf{T}_{3}$ & 7.99 & 7.36 & 7.67 & 9.51 & 8.80 & 9.16 & 2.66 & 2.27 & 2.47 \\
\hline $\mathbf{D}_{2} \mathbf{T}_{4}$ & 8.09 & 7.41 & 7.75 & 9.72 & 8.87 & 9.30 & 2.78 & 2.44 & 2.61 \\
\hline$D_{2} T_{5}$ & 6.85 & 6.34 & 6.60 & 8.34 & 8.16 & 8.25 & 2.32 & 2.16 & 2.24 \\
\hline$D_{2} T_{6}$ & 8.17 & 8.07 & 8.12 & 10.63 & 10.19 & 10.41 & 3.06 & 3.04 & 3.05 \\
\hline $\mathbf{D}_{2} \mathbf{T}_{7}$ & 8.16 & 8.07 & 8.12 & 10.61 & 10.19 & 10.40 & 3.06 & 3.04 & 3.05 \\
\hline $\mathbf{D}_{2} \mathbf{T}_{8}$ & 8.16 & 8.06 & 8.11 & 10.63 & 10.20 & 10.42 & 3.06 & 3.04 & 3.05 \\
\hline$D_{3} T_{1}$ & 5.25 & 5.17 & 5.21 & 7.13 & 6.76 & 6.95 & 2.14 & 1.86 & 2.00 \\
\hline$D_{3} T_{2}$ & 7.67 & 7.03 & 7.35 & 8.95 & 8.28 & 8.62 & 2.44 & 2.06 & 2.25 \\
\hline $\mathbf{D}_{3} \mathbf{T}_{3}$ & 7.91 & 7.29 & 7.60 & 9.42 & 8.71 & 9.07 & 2.64 & 2.25 & 2.45 \\
\hline $\mathbf{D}_{3} \mathbf{T}_{4}$ & 8.01 & 7.33 & 7.67 & 9.62 & 8.78 & 9.20 & 2.76 & 2.42 & 2.59 \\
\hline$D_{3} T_{5}$ & 6.78 & 6.28 & 6.53 & 8.26 & 8.08 & 8.17 & 2.30 & 2.14 & 2.22 \\
\hline$D_{3} T_{6}$ & 8.09 & 7.98 & 8.04 & 10.51 & 10.09 & 10.30 & 3.03 & 3.01 & 3.02 \\
\hline $\mathbf{D}_{3} \mathbf{T}_{7}$ & 8.08 & 7.98 & 8.03 & 10.51 & 10.09 & 10.30 & 3.03 & 3.01 & 3.02 \\
\hline $\mathrm{D}_{3} \mathbf{T}_{8}$ & 8.08 & 7.97 & 8.03 & 10.53 & 10.10 & 10.31 & 3.03 & 3.01 & 3.02 \\
\hline S. Em. \pm & 0.22 & 0.21 & 0.11 & 0.26 & 0.26 & 0.13 & 0.12 & 0.10 & 0.08 \\
\hline C.D. @ $5 \%$ & NS & NS & NS & NS & NS & NS & NS & NS & NS \\
\hline
\end{tabular}

$\mathbf{D}_{1}: 1^{\text {st }}$ fortnight of June, $\mathbf{D}_{2}: 2^{\text {nd }}$ fortnight of June, $\mathbf{D}_{3}: 1^{\text {st }}$ fortnight of July

$\mathbf{T}_{1}$ : Water spray, $\mathbf{T}_{2}$ : Urea spray @ $2 \%, \mathbf{T}_{3}$ : DAP @ $2 \%, \mathbf{T}_{4}: \mathrm{KH}_{2} \mathrm{PO}_{4} @ 1 \%, \mathbf{T}_{5}:$ Boron @ 0.5\%, $\mathbf{T}_{6}:$ 19:19:19 NPK @ $3 \%+$ Boron @ $0.5 \%, \mathbf{T}_{7}: \mathrm{KNO}_{3} @ 1 \%+\mathrm{KH}_{2} \mathrm{PO}_{4} @ 0.5 \%, \mathbf{T}_{8}: \mathrm{KNO}_{3} @ 0.5 \%+\mathrm{KH}_{2} \mathrm{PO}_{4} @ 0.5 \%+$ Boron $0.5 \%$ NS: Non-significant 
Table.3 Effect of date of sowing and foliar application of nutrients on dry matter partitioning of soybean (cv. DSb 21) at harvest

\begin{tabular}{|c|c|c|c|c|c|c|}
\hline \multicolumn{7}{|c|}{ Dry matter partitioning (g/plant) } \\
\hline \multirow[t]{2}{*}{ Treatments } & \multicolumn{3}{|c|}{ Stem $\left(\right.$ g plant $\left.^{-1}\right)$} & \multicolumn{3}{|c|}{ Pod $\left(\right.$ g plant $\left.{ }^{-1}\right)$} \\
\hline & 2016 & 2017 & Pooled & 2016 & 2017 & Pooled \\
\hline \multicolumn{7}{|l|}{ Main plot (D) } \\
\hline$D_{1}$ & 12.26 & 11.74 & 12.00 & 22.45 & 21.21 & 21.83 \\
\hline $\mathbf{D}_{2}$ & 11.45 & 10.95 & 11.20 & 20.48 & 19.38 & 19.93 \\
\hline $\mathbf{D}_{3}$ & 11.33 & 10.84 & 11.09 & 19.82 & 18.61 & 19.22 \\
\hline S. Em. \pm & 0.04 & 0.03 & 0.02 & 0.40 & 0.37 & 0.27 \\
\hline C.D. @ $5 \%$ & 0.15 & 0.14 & 0.06 & 1.57 & 1.46 & 0.89 \\
\hline \multicolumn{7}{|l|}{ Sub Plot (T) } \\
\hline $\mathbf{T}_{1}$ & 10.31 & 9.25 & 9.78 & 19.56 & 18.10 & 18.83 \\
\hline $\mathbf{T}_{2}$ & 11.29 & 10.64 & 10.97 & 20.30 & 19.09 & 19.69 \\
\hline $\mathbf{T}_{3}$ & 11.36 & 10.81 & 11.08 & 20.68 & 19.54 & 20.11 \\
\hline $\mathbf{T}_{4}$ & 11.56 & 11.01 & 11.28 & 21.10 & 20.09 & 20.60 \\
\hline $\mathbf{T}_{5}$ & 11.22 & 10.21 & 10.72 & 20.01 & 18.52 & 19.26 \\
\hline $\mathbf{T}_{6}$ & 12.57 & 12.50 & 12.54 & 21.90 & 20.84 & 21.37 \\
\hline $\mathbf{T}_{7}$ & 12.56 & 12.49 & 12.52 & 21.90 & 20.84 & 21.37 \\
\hline $\mathbf{T}_{8}$ & 12.58 & 12.50 & 12.54 & 21.89 & 20.85 & 21.37 \\
\hline S. Em. \pm & 0.11 & 0.10 & 0.05 & 0.61 & 0.57 & 0.42 \\
\hline C.D. @ $5 \%$ & 0.30 & 0.28 & 0.14 & 1.75 & 1.62 & 1.18 \\
\hline \multicolumn{7}{|l|}{ Interactions $(\mathrm{D} \times \mathrm{T})$} \\
\hline$D_{1} T_{I}$ & 10.83 & 9.71 & 10.27 & 21.21 & 19.64 & 20.43 \\
\hline $\mathbf{D}_{1} \mathbf{T}_{2}$ & 11.85 & 11.17 & 11.51 & 22.03 & 20.83 & 21.43 \\
\hline $\mathbf{D}_{1} \mathbf{T}_{3}$ & 11.93 & 11.35 & 11.64 & 22.42 & 21.27 & 21.85 \\
\hline $\mathbf{D}_{1} \mathbf{T}_{4}$ & 12.14 & 11.56 & 11.85 & 22.86 & 21.82 & 22.34 \\
\hline $\mathbf{D}_{1} \mathbf{T}_{5}$ & 11.78 & 10.72 & 11.25 & 21.85 & 20.06 & 20.96 \\
\hline$D_{1} T_{6}$ & 13.20 & 13.13 & 13.16 & 23.09 & 22.03 & 22.56 \\
\hline $\mathbf{D}_{1} \mathbf{T}_{7}$ & 13.19 & 13.11 & 13.15 & 23.09 & 22.03 & 22.56 \\
\hline $\mathbf{D}_{1} \mathbf{T}_{8}$ & 13.21 & 13.13 & 13.17 & 23.08 & 22.03 & 22.56 \\
\hline$D_{2} T_{1}$ & 10.10 & 9.06 & 9.58 & 19.09 & 17.63 & 18.36 \\
\hline$D_{2} T_{2}$ & 11.06 & 10.43 & 10.75 & 19.83 & 18.61 & 19.22 \\
\hline $\mathbf{D}_{2} \mathbf{T}_{3}$ & 11.13 & 10.59 & 10.86 & 20.20 & 19.21 & 19.71 \\
\hline$D_{2} T_{4}$ & 11.33 & 10.79 & 11.06 & 20.63 & 19.73 & 20.18 \\
\hline $\mathbf{D}_{2} \mathbf{T}_{5}$ & 11.00 & 10.01 & 10.50 & 19.42 & 18.16 & 18.79 \\
\hline$D_{2} T_{6}$ & 12.32 & 12.25 & 12.28 & 21.55 & 20.56 & 21.06 \\
\hline $\mathbf{D}_{2} \mathbf{T}_{7}$ & 12.31 & 12.24 & 12.27 & 21.55 & 20.56 & 21.06 \\
\hline$D_{2} T_{8}$ & 12.33 & 12.25 & 12.29 & 21.54 & 20.56 & 21.05 \\
\hline $\mathbf{D}_{3} \mathbf{T}_{1}$ & 10.00 & 8.97 & 9.49 & 18.39 & 17.03 & 17.71 \\
\hline$D_{3} T_{2}$ & 10.95 & 10.32 & 10.64 & 19.03 & 17.82 & 18.43 \\
\hline$D_{3} T_{3}$ & 11.02 & 10.48 & 10.75 & 19.43 & 18.15 & 18.79 \\
\hline$D_{3} T_{4}$ & 11.21 & 10.68 & 10.95 & 19.82 & 18.73 & 19.27 \\
\hline$D_{3} T_{5}$ & 10.88 & 9.90 & 10.39 & 18.75 & 17.34 & 18.05 \\
\hline$D_{3} T_{6}$ & 12.19 & 12.13 & 12.16 & 21.05 & 19.94 & 20.50 \\
\hline $\mathbf{D}_{3} \mathbf{T}_{7}$ & 12.18 & 12.11 & 12.15 & 21.05 & 19.94 & 20.50 \\
\hline $\mathbf{D}_{3} \mathbf{T}_{8}$ & 12.20 & 12.13 & 12.16 & 21.06 & 19.95 & 20.51 \\
\hline S. Em. \pm & 0.32 & 0.30 & 0.15 & 0.69 & 0.70 & 0.67 \\
\hline C.D. @ $5 \%$ & NS & NS & NS & NS & NS & NS \\
\hline
\end{tabular}

$\mathbf{D}_{1}: 1^{\text {st }}$ fortnight of June, $\mathbf{D}_{2}: 2^{\text {nd }}$ fortnight of June, $\mathbf{D}_{3}: 1^{\text {st }}$ fortnight of July

$\mathbf{T}_{1}$ : Water spray, $\mathbf{T}_{2}:$ Urea spray @ $2 \%, \mathbf{T}_{3}:$ DAP @ $2 \%, \mathbf{T}_{4}: \mathrm{KH}_{2} \mathrm{PO}_{4} @ 1 \%, \mathbf{T}_{5}:$ Boron @ 0.5 \%, $\mathbf{T}_{6}:$ 19:19:19 NPK @ $3 \%+$ Boron@ $0.5 \%, \mathbf{T}_{7}: \mathrm{KNO}_{3} @ 1 \%+\mathrm{KH}_{2} \mathrm{PO}_{4} @ 0.5 \%, \mathbf{T}_{8}: \mathrm{KNO}_{3} @ 0.5 \%+\mathrm{KH}_{2} \mathrm{PO}_{4} @ 0.5 \%+$ Boron $0.5 \%$, NS: Nonsignificant 
Table.4 Effect of date of sowing and foliar application of nutrients on total dry matter at different growth stages of soybean (cv. DSb 21)

\begin{tabular}{|c|c|c|c|c|c|c|c|c|c|}
\hline \multicolumn{10}{|c|}{ Total dry matter (g) } \\
\hline \multirow[t]{2}{*}{ Treatments } & \multicolumn{3}{|c|}{30 DAS $\left(\right.$ g plant $\left.^{-1}\right)$} & \multicolumn{3}{|c|}{60 DAS $\left(\right.$ g plant $\left.^{-1}\right)$} & \multicolumn{3}{|c|}{ At harvest (g plant ${ }^{-1}$ ) } \\
\hline & 2016 & 2017 & Pooled & 2016 & 2017 & Pooled & 2016 & 2017 & Pooled \\
\hline \multicolumn{10}{|l|}{ Main plot (D) } \\
\hline $\mathbf{D}_{1}$ & 5.07 & 4.94 & 5.00 & 21.12 & 19.98 & 20.55 & 34.72 & 32.95 & 33.83 \\
\hline $\mathbf{D}_{2}$ & 3.94 & 3.85 & 3.90 & 19.72 & 18.65 & 19.18 & 31.92 & 30.33 & 31.13 \\
\hline $\mathbf{D}_{3}$ & 2.95 & 2.87 & 2.91 & 19.52 & 18.46 & 18.99 & 31.15 & 29.45 & 30.30 \\
\hline S. Em. \pm & 0.05 & 0.04 & 0.02 & 0.06 & 0.06 & 0.03 & 0.62 & 0.57 & 0.42 \\
\hline C.D. @ 5 \% & 0.18 & 0.17 & 0.07 & 0.24 & 0.23 & 0.10 & 2.42 & 2.22 & 1.37 \\
\hline \multicolumn{10}{|l|}{ Sub Plot (T) } \\
\hline $\mathbf{T}_{1}$ & 3.58 & 3.46 & 3.52 & 14.96 & 14.22 & 14.59 & 29.87 & 27.35 & 28.61 \\
\hline $\mathbf{T}_{2}$ & 3.45 & 3.37 & 3.41 & 19.65 & 17.91 & 18.78 & 31.59 & 29.73 & 30.66 \\
\hline $\mathbf{T}_{3}$ & 3.73 & 3.60 & 3.67 & 20.58 & 18.81 & 19.70 & 32.04 & 30.35 & 31.20 \\
\hline $\mathbf{T}_{4}$ & 3.89 & 3.80 & 3.84 & 21.02 & 19.10 & 20.06 & 32.66 & 31.10 & 31.88 \\
\hline $\mathbf{T}_{5}$ & 3.95 & 3.82 & 3.88 & 17.87 & 17.00 & 17.44 & 31.23 & 28.73 & 29.98 \\
\hline$T_{6}$ & 4.86 & 4.72 & 4.79 & 22.30 & 21.73 & 22.02 & 34.46 & 33.34 & 33.90 \\
\hline $\mathbf{T}_{7}$ & 3.95 & 3.91 & 3.93 & 22.28 & 21.73 & 22.00 & 34.45 & 33.33 & 33.89 \\
\hline $\mathbf{T}_{8}$ & 4.46 & 4.41 & 4.44 & 22.30 & 21.73 & 22.02 & 34.47 & 33.35 & 33.91 \\
\hline S. Em. \pm & 0.11 & 0.11 & 0.06 & 0.15 & 0.15 & 0.08 & 0.97 & 0.88 & 0.65 \\
\hline C.D. @ $5 \%$ & 0.32 & 0.31 & 0.15 & 0.43 & 0.43 & 0.21 & 2.75 & 2.51 & 1.84 \\
\hline \multicolumn{10}{|l|}{ Interactions $(\mathrm{D} \times \mathrm{T})$} \\
\hline$D_{1} T_{I}$ & 5.14 & 4.93 & 5.04 & 15.71 & 14.93 & 15.32 & 32.04 & 29.35 & 30.70 \\
\hline $\mathbf{D}_{1} \mathbf{T}_{2}$ & 4.53 & 4.44 & 4.49 & 20.63 & 18.80 & 19.72 & 33.88 & 32.00 & 32.94 \\
\hline $\mathbf{D}_{1} \mathbf{T}_{3}$ & 4.86 & 4.71 & 4.79 & 21.61 & 19.76 & 20.68 & 34.35 & 32.62 & 33.49 \\
\hline $\mathbf{D}_{1} \mathbf{T}_{4}$ & 5.02 & 4.93 & 4.98 & 22.07 & 20.05 & 21.06 & 35.00 & 33.38 & 34.19 \\
\hline $\mathbf{D}_{1} \mathbf{T}_{5}$ & 5.10 & 4.82 & 4.96 & 18.76 & 17.85 & 18.31 & 33.63 & 30.78 & 32.21 \\
\hline $\mathbf{D}_{1} \mathbf{T}_{6}$ & 5.66 & 5.50 & 5.58 & 23.41 & 22.82 & 23.12 & 36.29 & 35.16 & 35.72 \\
\hline $\mathbf{D}_{1} \mathbf{T}_{7}$ & 5.00 & 4.96 & 4.98 & 23.39 & 22.82 & 23.11 & 36.27 & 35.15 & 35.71 \\
\hline $\mathbf{D}_{1} \mathbf{T}_{8}$ & 5.24 & 5.19 & 5.22 & 23.41 & 22.82 & 23.12 & 36.29 & 35.16 & 35.73 \\
\hline $\mathbf{D}_{2} \mathbf{T}_{1}$ & 3.18 & 3.06 & 3.12 & 14.66 & 13.94 & 14.30 & 29.19 & 26.69 & 27.94 \\
\hline $\mathbf{D}_{2} \mathbf{T}_{2}$ & 3.45 & 3.38 & 3.42 & 19.25 & 17.55 & 18.40 & 30.89 & 29.04 & 29.97 \\
\hline $\mathbf{D}_{2} \mathbf{T}_{3}$ & 3.68 & 3.52 & 3.60 & 20.17 & 18.44 & 19.30 & 31.33 & 29.80 & 30.57 \\
\hline $\mathrm{D}_{2} \mathbf{T}_{4}$ & 3.93 & 3.83 & 3.88 & 20.60 & 18.72 & 19.66 & 31.96 & 30.52 & 31.24 \\
\hline $\mathbf{D}_{2} \mathbf{T}_{5}$ & 3.95 & 3.91 & 3.93 & 17.51 & 16.66 & 17.09 & 30.42 & 28.17 & 29.29 \\
\hline $\mathrm{D}_{2} \mathbf{T}_{6}$ & 4.84 & 4.73 & 4.79 & 21.85 & 21.30 & 21.58 & 33.86 & 32.81 & 33.34 \\
\hline $\mathbf{D}_{2} \mathbf{T}_{7}$ & 4.01 & 3.98 & 4.00 & 21.83 & 21.30 & 21.56 & 33.85 & 32.80 & 33.33 \\
\hline $\mathrm{D}_{2} \mathrm{~T}_{8}$ & 4.45 & 4.42 & 4.44 & 21.85 & 21.30 & 21.58 & 33.86 & 32.81 & 33.34 \\
\hline $\mathrm{D}_{3} \mathrm{~T}_{1}$ & 2.42 & 2.39 & 2.41 & 14.51 & 13.80 & 14.16 & 28.39 & 26.00 & 27.20 \\
\hline $\mathbf{D}_{3} \mathbf{T}_{2}$ & 2.37 & 2.29 & 2.33 & 19.06 & 17.37 & 18.22 & 29.98 & 28.15 & 29.06 \\
\hline$D_{3} T_{3}$ & 2.66 & 2.57 & 2.62 & 19.96 & 18.24 & 19.10 & 30.45 & 28.63 & 29.54 \\
\hline$D_{3} T_{4}$ & 2.72 & 2.64 & 2.68 & 20.39 & 18.53 & 19.46 & 31.03 & 29.40 & 30.22 \\
\hline $\mathbf{D}_{3} \mathbf{T}_{5}$ & 2.80 & 2.73 & 2.76 & 17.33 & 16.49 & 16.91 & 29.63 & 27.24 & 28.44 \\
\hline$D_{3} T_{6}$ & 4.07 & 3.93 & 4.00 & 21.63 & 21.07 & 21.35 & 33.24 & 32.07 & 32.66 \\
\hline $\mathbf{D}_{3} \mathbf{T}_{7}$ & 2.84 & 2.78 & 2.81 & 21.61 & 21.07 & 21.34 & 33.23 & 32.05 & 32.64 \\
\hline$D_{3} T_{8}$ & 3.68 & 3.63 & 3.66 & 21.63 & 21.08 & 21.36 & 33.26 & 32.08 & 32.67 \\
\hline S. Em. \pm & 0.34 & 0.32 & 0.17 & 0.46 & 0.45 & 0.23 & 1.67 & 1.53 & 1.13 \\
\hline C.D. @ $5 \%$ & NS & NS & NS & NS & NS & NS & NS & NS & NS \\
\hline
\end{tabular}

$\mathbf{D}_{1}: 1^{\text {st }}$ fortnight of June, $\mathbf{D}_{2}: 2^{\text {nd }}$ fortnight of June, $\mathbf{D}_{3}: 1^{\text {st }}$ fortnight of July

$\mathbf{T}_{1}$ : Water spray, $\mathbf{T}_{2}$ : Urea spray @ 2\%, $\mathbf{T}_{3}$ : DAP @ 2\%, $\mathbf{T}_{4}: \mathrm{KH}_{2} \mathrm{PO}_{4} @ 1 \%, \mathbf{T}_{5}:$ Boron @ 0.5\%, $\mathbf{T}_{6}: 19: 19: 19 \mathrm{NPK} @ 3 \%+$ Boron@0.5\%, $\mathbf{T}_{7}: \mathrm{KNO}_{3} @ 1 \%+\mathrm{KH}_{2} \mathrm{PO}_{4} @ 0.5 \%, \mathbf{T}_{8}: \mathrm{KNO}_{3} @ 0.5 \%+\mathrm{KH}_{2} \mathrm{PO}_{4} @ 0.5 \%+$ Boron $0.5 \%$

NS: Non-significant 
Table.5 Effect of date of sowing and foliar application of nutrients on crop growth rate at different stages of growth in soybean (cv. DSb 21)

\begin{tabular}{|c|c|c|c|c|c|c|c|c|c|c|c|c|}
\hline \multirow[t]{3}{*}{ Treatments } & \multicolumn{12}{|c|}{ Crop growth rate $\left(\mathrm{g} \mathrm{m}^{-2}\right.$ day $\left.^{-1}\right)$} \\
\hline & \multicolumn{3}{|c|}{ 30-45 DAS } & \multicolumn{3}{|c|}{ 45-60 DAS } & \multicolumn{3}{|c|}{ 60-75 DAS } & \multicolumn{3}{|c|}{ 75- harvest } \\
\hline & 2016 & 2017 & Pooled & 2016 & 2017 & Pooled & 2016 & 2017 & Pooled & 2016 & 2017 & Pooled \\
\hline \multicolumn{13}{|l|}{ Main plot (D) } \\
\hline $\mathbf{D}_{1}$ & 12.61 & 12.60 & 12.61 & 29.04 & 27.30 & 28.17 & 17.30 & 17.16 & 17.23 & 14.40 & 13.50 & 13.95 \\
\hline $\mathbf{D}_{2}$ & 11.97 & 11.96 & 11.97 & 26.80 & 24.01 & 25.41 & 16.13 & 15.98 & 16.06 & 13.11 & 12.34 & 12.73 \\
\hline $\mathbf{D}_{3}$ & 11.92 & 11.91 & 11.92 & 23.25 & 21.15 & 22.20 & 14.99 & 14.61 & 14.80 & 11.22 & 10.75 & 10.99 \\
\hline S. Em. \pm & 0.07 & 0.07 & 0.03 & 0.10 & 0.09 & 0.05 & 0.04 & 0.04 & 0.02 & 0.05 & 0.05 & 0.02 \\
\hline C.D. @ 5 \% & 0.26 & 0.26 & 0.11 & 0.38 & 0.36 & 0.15 & 0.16 & 0.17 & 0.07 & 0.20 & 0.18 & 0.08 \\
\hline \multicolumn{13}{|l|}{ Sub Plot (T) } \\
\hline $\mathbf{T}_{1}$ & 12.70 & 12.68 & 12.69 & 24.44 & 22.23 & 23.34 & 14.54 & 14.08 & 14.31 & 11.23 & 10.60 & 10.92 \\
\hline $\mathbf{T}_{2}$ & 11.36 & 11.34 & 11.35 & 25.47 & 23.32 & 24.40 & 15.29 & 15.05 & 15.17 & 12.17 & 11.61 & 11.89 \\
\hline $\mathbf{T}_{3}$ & 12.33 & 12.32 & 12.32 & 26.14 & 23.88 & 25.01 & 15.77 & 15.39 & 15.58 & 12.60 & 12.09 & 12.35 \\
\hline $\mathbf{T}_{4}$ & 11.67 & 11.66 & 11.66 & 27.03 & 24.60 & 25.81 & 16.31 & 16.20 & 16.26 & 13.17 & 12.49 & 12.83 \\
\hline $\mathbf{T}_{5}$ & 12.15 & 12.14 & 12.15 & 25.06 & 22.65 & 23.85 & 14.99 & 14.57 & 14.78 & 11.72 & 11.18 & 11.45 \\
\hline $\mathbf{T}_{6}$ & 12.39 & 12.38 & 12.38 & 27.04 & 25.52 & 26.28 & 17.40 & 17.34 & 17.37 & 14.12 & 13.20 & 13.66 \\
\hline $\mathbf{T}_{7}$ & 12.39 & 12.38 & 12.38 & 27.85 & 25.52 & 26.69 & 17.40 & 17.34 & 17.37 & 14.12 & 13.20 & 13.66 \\
\hline $\mathbf{T}_{8}$ & 12.38 & 12.37 & 12.37 & 27.86 & 25.53 & 26.70 & 17.41 & 17.35 & 17.38 & 14.13 & 13.21 & 13.67 \\
\hline S. Em. \pm & 0.21 & 0.21 & 0.10 & 0.23 & 0.22 & 0.11 & 0.10 & 0.11 & 0.05 & 0.12 & 0.12 & 0.06 \\
\hline C.D. @ $5 \%$ & NS & NS & NS & 0.66 & 0.62 & 0.32 & 0.29 & 0.30 & 0.15 & 0.35 & 0.33 & 0.17 \\
\hline \multicolumn{13}{|l|}{ Interactions $(\mathrm{D} \times \mathrm{T})$} \\
\hline $\mathrm{D}_{1} \mathrm{~T}_{\mathrm{I}}$ & 15.96 & 15.94 & 15.95 & 27.09 & 25.12 & 26.10 & 15.36 & 15.09 & 15.23 & 12.36 & 11.63 & 12.00 \\
\hline $\mathbf{D}_{1} \mathbf{T}_{2}$ & 11.42 & 11.40 & 11.41 & 28.27 & 26.34 & 27.31 & 16.65 & 16.46 & 16.56 & 13.65 & 12.72 & 13.18 \\
\hline $\mathbf{D}_{1} \mathbf{T}_{3}$ & 12.37 & 12.36 & 12.37 & 28.96 & 26.94 & 27.95 & 17.25 & 17.06 & 17.16 & 14.25 & 13.21 & 13.73 \\
\hline $\mathbf{D}_{1} \mathbf{T}_{4}$ & 11.70 & 11.69 & 11.70 & 29.63 & 27.46 & 28.55 & 17.98 & 17.84 & 17.91 & 14.98 & 13.82 & 14.40 \\
\hline $\mathrm{D}_{1} \mathbf{T}_{5}$ & 12.19 & 12.18 & 12.18 & 27.63 & 25.63 & 26.63 & 16.06 & 15.89 & 15.98 & 13.06 & 12.18 & 12.62 \\
\hline $\mathbf{D}_{1} \mathbf{T}_{6}$ & 12.43 & 12.43 & 12.43 & 30.24 & 28.97 & 29.61 & 18.37 & 18.30 & 18.34 & 15.62 & 14.81 & 15.22 \\
\hline $\mathbf{D}_{1} \mathbf{T}_{7}$ & 12.43 & 12.43 & 12.43 & 30.24 & 28.97 & 29.61 & 18.37 & 18.30 & 18.34 & 15.62 & 14.81 & 15.22 \\
\hline $\mathbf{D}_{1} \mathbf{T}_{8}$ & 12.42 & 12.41 & 12.41 & 30.25 & 28.98 & 29.62 & 18.38 & 18.31 & 18.35 & 15.63 & 14.82 & 15.23 \\
\hline $\mathrm{D}_{2} \mathrm{~T}_{1}$ & 11.11 & 11.09 & 11.10 & 25.16 & 22.17 & 23.66 & 14.34 & 14.12 & 14.23 & 11.32 & 10.33 & 10.83 \\
\hline
\end{tabular}


Table.5 Contd....

\begin{tabular}{|c|c|c|c|c|c|c|c|c|c|c|c|c|}
\hline \multirow[t]{3}{*}{ Treatments } & \multicolumn{12}{|c|}{ Crop growth rate $\left(\mathrm{g} \mathrm{m}^{-2}\right.$ day $\left.^{-1}\right)$} \\
\hline & \multicolumn{3}{|c|}{ 30-45 DAS } & \multicolumn{3}{|c|}{ 45-60 DAS } & \multicolumn{3}{|c|}{ 60-75 DAS } & \multicolumn{3}{|c|}{ 75- harvest } \\
\hline & 2016 & 2017 & Pooled & 2016 & 2017 & Pooled & 2016 & 2017 & Pooled & 2016 & 2017 & Pooled \\
\hline $\mathbf{D}_{2} \mathbf{T}_{2}$ & 11.35 & 11.34 & 11.35 & 26.12 & 23.16 & 24.64 & 15.02 & 14.81 & 14.92 & 12.01 & 11.69 & 11.85 \\
\hline $\mathbf{D}_{\mathbf{2}} \mathbf{T}_{\mathbf{3}}$ & 12.33 & 12.33 & 12.33 & 26.73 & 23.67 & 25.20 & 15.21 & 15.01 & 15.11 & 12.55 & 12.16 & 12.35 \\
\hline $\mathbf{D}_{2} \mathbf{T}_{4}$ & 11.67 & 11.67 & 11.67 & 27.89 & 24.53 & 26.21 & 15.95 & 15.88 & 15.92 & 12.98 & 12.63 & 12.81 \\
\hline $\mathbf{D}_{2} \mathbf{T}_{5}$ & 12.15 & 12.14 & 12.15 & 25.91 & 22.69 & 24.30 & 14.89 & 14.58 & 14.74 & 11.70 & 11.26 & 11.48 \\
\hline $\mathrm{D}_{2} \mathrm{~T}_{6}$ & 12.39 & 12.38 & 12.39 & 25.91 & 25.29 & 25.60 & 17.88 & 17.81 & 17.85 & 14.77 & 13.55 & 14.16 \\
\hline $\mathbf{D}_{2} \mathbf{T}_{7}$ & 12.39 & 12.38 & 12.39 & 28.33 & 25.29 & 26.81 & 17.88 & 17.81 & 17.85 & 14.77 & 13.55 & 14.16 \\
\hline $\mathrm{D}_{2} \mathbf{T}_{8}$ & 12.38 & 12.37 & 12.37 & 28.34 & 25.30 & 26.82 & 17.89 & 17.82 & 17.86 & 14.78 & 13.56 & 14.17 \\
\hline $\mathbf{D}_{3} \mathbf{T}_{1}$ & 11.03 & 11.02 & 11.03 & 21.09 & 19.39 & 20.24 & 13.91 & 13.02 & 13.47 & 10.02 & 9.85 & 9.94 \\
\hline $\mathbf{D}_{3} \mathbf{T}_{2}$ & 11.31 & 11.29 & 11.30 & 22.03 & 20.46 & 21.25 & 14.21 & 13.87 & 14.04 & 10.85 & 10.43 & 10.64 \\
\hline $\mathbf{D}_{3} \mathbf{T}_{\mathbf{3}}$ & 12.28 & 12.26 & 12.27 & 22.73 & 21.02 & 21.87 & 14.85 & 14.09 & 14.47 & 11.01 & 10.89 & 10.95 \\
\hline $\mathbf{D}_{3} \mathbf{T}_{4}$ & 11.63 & 11.62 & 11.63 & 23.56 & 21.81 & 22.69 & 15.01 & 14.86 & 14.94 & 11.54 & 11.01 & 11.28 \\
\hline $\mathbf{D}_{\mathbf{3}} \mathbf{T}_{\mathbf{5}}$ & 12.12 & 12.11 & 12.12 & 21.64 & 19.62 & 20.63 & 14.02 & 13.23 & 13.63 & 10.40 & 10.10 & 10.25 \\
\hline$D_{3} T_{6}$ & 12.34 & 12.33 & 12.34 & 24.98 & 22.30 & 23.64 & 15.96 & 15.92 & 15.94 & 11.97 & 11.24 & 11.61 \\
\hline $\mathbf{D}_{\mathbf{3}} \mathbf{T}_{7}$ & 12.34 & 12.33 & 12.34 & 24.98 & 22.30 & 23.64 & 15.96 & 15.92 & 15.94 & 11.97 & 11.24 & 11.61 \\
\hline $\mathbf{D}_{3} \mathbf{T}_{8}$ & 12.33 & 12.33 & 12.33 & 24.99 & 22.31 & 23.65 & 15.97 & 15.93 & 15.95 & 11.98 & 11.25 & 11.62 \\
\hline S. Em. \pm & 0.63 & 0.63 & 0.31 & 0.70 & 0.65 & 0.34 & 0.30 & 0.32 & 0.16 & 0.37 & 0.35 & 0.18 \\
\hline C.D. @ 5 \% & NS & NS & NS & NS & NS & NS & NS & NS & NS & NS & NS & NS \\
\hline
\end{tabular}

$\mathbf{D}_{1}: 1^{\text {st }}$ fortnight of June, $\mathbf{D}_{2}: 2^{\text {nd }}$ fortnight of June, $\mathbf{D}_{3}: 1^{\text {st }}$ fortnight of July

$\mathbf{T}_{1}$ : Water spray, $\mathbf{T}_{2}$ : Urea spray @ $2 \%, \mathbf{T}_{3}$ : DAP @ 2\%, $\mathbf{T}_{\mathbf{4}}: \mathrm{KH}_{2} \mathrm{PO}_{4} @ 1 \%, \mathbf{T}_{\mathbf{5}}$ : Boron @ 0.5\%, $\mathbf{T}_{\mathbf{6}}: 19: 19: 19 \mathrm{NPK} @ 3 \%+\mathrm{Boron} @ 0.5 \%, \mathbf{T}_{7}: \mathrm{KNO}_{3} @ 1$

$\%+\mathrm{KH}_{2} \mathrm{PO}_{4} @ 0.5 \%, \mathrm{~T}_{8}: \mathrm{KNO}_{3} @ 0.5 \%+\mathrm{KH}_{2} \mathrm{PO}_{4} @ 0.5 \%+$ Boron $0.5 \%$, NS: Non-significant 
Table.6 Effect of date of sowing and foliar application of nutrients on leaf area duration at different growth stages of soybean (cv. DSb 21)

\begin{tabular}{|c|c|c|c|c|c|c|c|c|c|}
\hline \multirow{3}{*}{\begin{tabular}{|r|} 
Treatments \\
Main plot (D) \\
\end{tabular}} & \multicolumn{9}{|c|}{ Leaf area duration (days) } \\
\hline & \multicolumn{3}{|c|}{ 30-45 DAS } & \multicolumn{3}{|c|}{ 45-60 DAS } & \multicolumn{3}{|c|}{ 60-75 DAS } \\
\hline & 2016 & 2017 & Pooled & 2016 & 2017 & Pooled & 2016 & 2017 & Pooled \\
\hline$D_{1}$ & 36.89 & 36.27 & 36.58 & 66.54 & 66.03 & 66.28 & 62.85 & 61.28 & 62.06 \\
\hline$D_{2}$ & 32.93 & 32.40 & 32.67 & 62.56 & 62.06 & 62.31 & 58.20 & 57.76 & 57.98 \\
\hline $\mathbf{D}_{3}$ & 29.38 & 29.23 & 29.31 & 59.39 & 58.47 & 58.93 & 55.95 & 54.83 & 55.39 \\
\hline S. Em. \pm & 0.17 & 0.15 & 0.08 & 0.27 & 0.29 & 0.14 & 0.24 & 0.23 & 0.12 \\
\hline C.D. @ $5 \%$ & 0.66 & 0.59 & 0.26 & 1.05 & 1.13 & 0.45 & 0.94 & 0.91 & 0.39 \\
\hline \multicolumn{10}{|l|}{ Sub Plot (T) } \\
\hline $\mathbf{T}_{1}$ & 37.16 & 36.77 & 36.97 & 59.31 & 58.08 & 58.70 & 56.67 & 54.78 & 55.72 \\
\hline $\mathbf{T}_{2}$ & 32.24 & 31.93 & 32.08 & 61.75 & 61.13 & 61.44 & 58.03 & 57.12 & 57.58 \\
\hline$T_{3}$ & 32.51 & 32.05 & 32.28 & 62.42 & 61.80 & 62.11 & 58.68 & 57.73 & 58.21 \\
\hline $\mathbf{T}_{4}$ & 32.35 & 31.96 & 32.16 & 63.13 & 62.32 & 62.73 & 59.26 & 58.32 & 58.79 \\
\hline $\mathbf{T}_{5}$ & 32.42 & 32.01 & 32.21 & 61.18 & 60.15 & 60.67 & 57.36 & 56.36 & 56.86 \\
\hline$T_{6}$ & 32.65 & 32.14 & 32.40 & 64.95 & 64.66 & 64.81 & 60.66 & 59.77 & 60.22 \\
\hline $\mathbf{T}_{7}$ & 32.59 & 32.08 & 32.34 & 64.95 & 64.66 & 64.81 & 60.66 & 59.77 & 60.22 \\
\hline $\mathbf{T}_{8}$ & 32.63 & 32.12 & 32.38 & 64.96 & 64.67 & 64.82 & 60.67 & 59.78 & 60.23 \\
\hline S. Em. \pm & 0.59 & 0.58 & 0.29 & 0.63 & 0.71 & 0.34 & 0.63 & 0.64 & 0.32 \\
\hline C.D. @ 5 \% & NS & NS & NS & 1.81 & 2.02 & 0.95 & 1.80 & 1.83 & 0.90 \\
\hline \multicolumn{10}{|l|}{$\begin{array}{l}\text { Interactions (D } \\
\times \mathrm{T})\end{array}$} \\
\hline$D_{1} T_{I}$ & 49.92 & 49.01 & 49.47 & 63.89 & 62.31 & 63.10 & 60.46 & 57.65 & 59.06 \\
\hline$D_{1} T_{2}$ & 34.96 & 34.34 & 34.65 & 65.61 & 65.15 & 65.38 & 62.09 & 60.38 & 61.24 \\
\hline $\mathbf{D}_{1} \mathbf{T}_{3}$ & 35.01 & 34.45 & 34.73 & 66.17 & 66.10 & 66.14 & 62.81 & 61.03 & 61.92 \\
\hline$D_{1} T_{4}$ & 34.98 & 34.40 & 34.69 & 66.84 & 66.35 & 66.60 & 63.08 & 61.62 & 62.35 \\
\hline$D_{1} T_{5}$ & 34.99 & 34.40 & 34.70 & 65.09 & 64.35 & 64.72 & 61.34 & 59.72 & 60.53 \\
\hline $\mathrm{D}_{1} \mathrm{~T}_{6}$ & 35.10 & 34.54 & 34.82 & 68.24 & 67.98 & 68.11 & 64.33 & 63.27 & 63.80 \\
\hline $\mathbf{D}_{1} \mathbf{T}_{7}$ & 35.05 & 34.50 & 34.78 & 68.24 & 67.98 & 68.11 & 64.33 & 63.27 & 63.80 \\
\hline$D_{1} T_{8}$ & 35.08 & 34.53 & 34.81 & 68.25 & 67.99 & 68.12 & 64.34 & 63.28 & 63.81 \\
\hline $\mathrm{D}_{2} \mathrm{~T}_{1}$ & 32.56 & 32.34 & 32.45 & 58.36 & 57.68 & 58.02 & 55.69 & 55.06 & 55.38 \\
\hline$D_{2} T_{2}$ & 32.63 & 32.38 & 32.51 & 61.12 & 60.68 & 60.90 & 56.98 & 56.63 & 56.80 \\
\hline$D_{2} T_{3}$ & 33.05 & 32.42 & 32.73 & 61.86 & 61.28 & 61.57 & 57.38 & 57.12 & 57.25 \\
\hline$D_{2} T_{4}$ & 32.82 & 32.35 & 32.59 & 62.59 & 61.98 & 62.29 & 58.69 & 57.71 & 58.20 \\
\hline$D_{2} T_{5}$ & 32.96 & 32.40 & 32.68 & 60.54 & 59.46 & 60.00 & 56.22 & 56.08 & 56.15 \\
\hline$D_{2} T_{6}$ & 33.18 & 32.47 & 32.82 & 65.34 & 65.13 & 65.23 & 60.22 & 59.81 & 60.02 \\
\hline $\mathbf{D}_{2} \mathbf{T}_{7}$ & 33.10 & 32.40 & 32.75 & 65.34 & 65.13 & 65.23 & 60.22 & 59.81 & 60.02 \\
\hline$D_{2} T_{8}$ & 33.15 & 32.45 & 32.80 & 65.35 & 65.14 & 65.25 & 60.23 & 59.82 & 60.02 \\
\hline$D_{3} T_{1}$ & 28.99 & 28.97 & 28.98 & 55.68 & 54.25 & 54.97 & 53.85 & 51.63 & 52.74 \\
\hline$D_{3} T_{2}$ & 29.11 & 29.08 & 29.10 & 58.51 & 57.56 & 58.04 & 55.02 & 54.35 & 54.69 \\
\hline$D_{3} T_{3}$ & 29.48 & 29.30 & 29.39 & 59.23 & 58.03 & 58.63 & 55.86 & 55.04 & 55.45 \\
\hline $\mathrm{D}_{3} \mathbf{T}_{4}$ & 29.25 & 29.14 & 29.19 & 59.97 & 58.63 & 59.30 & 56.01 & 55.62 & 55.82 \\
\hline$D_{3} T_{5}$ & 29.30 & 29.22 & 29.26 & 57.91 & 56.64 & 57.27 & 54.52 & 53.28 & 53.90 \\
\hline$D_{3} T_{6}$ & 29.67 & 29.41 & 29.54 & 61.27 & 60.88 & 61.08 & 57.44 & 56.23 & 56.83 \\
\hline $\mathbf{D}_{3} \mathbf{T}_{7}$ & 29.62 & 29.34 & 29.48 & 61.27 & 60.88 & 61.08 & 57.44 & 56.23 & 56.83 \\
\hline$D_{3} T_{8}$ & 29.65 & 29.40 & 29.53 & 61.28 & 60.89 & 61.09 & 57.45 & 56.24 & 56.85 \\
\hline S. Em. \pm & 1.77 & 1.74 & 0.88 & 1.90 & 2.13 & 1.01 & 1.90 & 1.93 & 0.96 \\
\hline C.D.@5\% & NS & NS & NS & NS & NS & NS & NS & NS & NS \\
\hline
\end{tabular}

$\mathbf{D}_{1}: 1^{\text {st }}$ fortnight of June, $\mathbf{D}_{2}: 2^{\text {nd }}$ fortnight of June, $\mathbf{D}_{3}: 1^{\text {st }}$ fortnight of July

$\mathbf{T}_{1}$ : Water spray, $\mathbf{T}_{2}$ : Urea spray @ $2 \%, \mathbf{T}_{3}$ : DAP @ 2\%, $\mathbf{T}_{4}: \mathrm{KH}_{2} \mathrm{PO}_{4} @ 1 \%, \mathbf{T}_{5}:$ Boron @ 0.5\%, $\mathbf{T}_{6}:$ 19:19:19 NPK@3\%+Boron@0.5\%, T $\mathbf{T}_{7}: \mathrm{KNO}_{3} @ 1 \%+\mathrm{KH}_{2} \mathrm{PO}_{4} @ 0.5 \%, \mathbf{T}_{8}: \mathrm{KNO}_{3} @ 0.5 \%+\mathrm{KH}_{2} \mathrm{PO}_{4} @ 0.5 \%+$ Boron $0.5 \%$, NS: Non-significant 
Fig.1

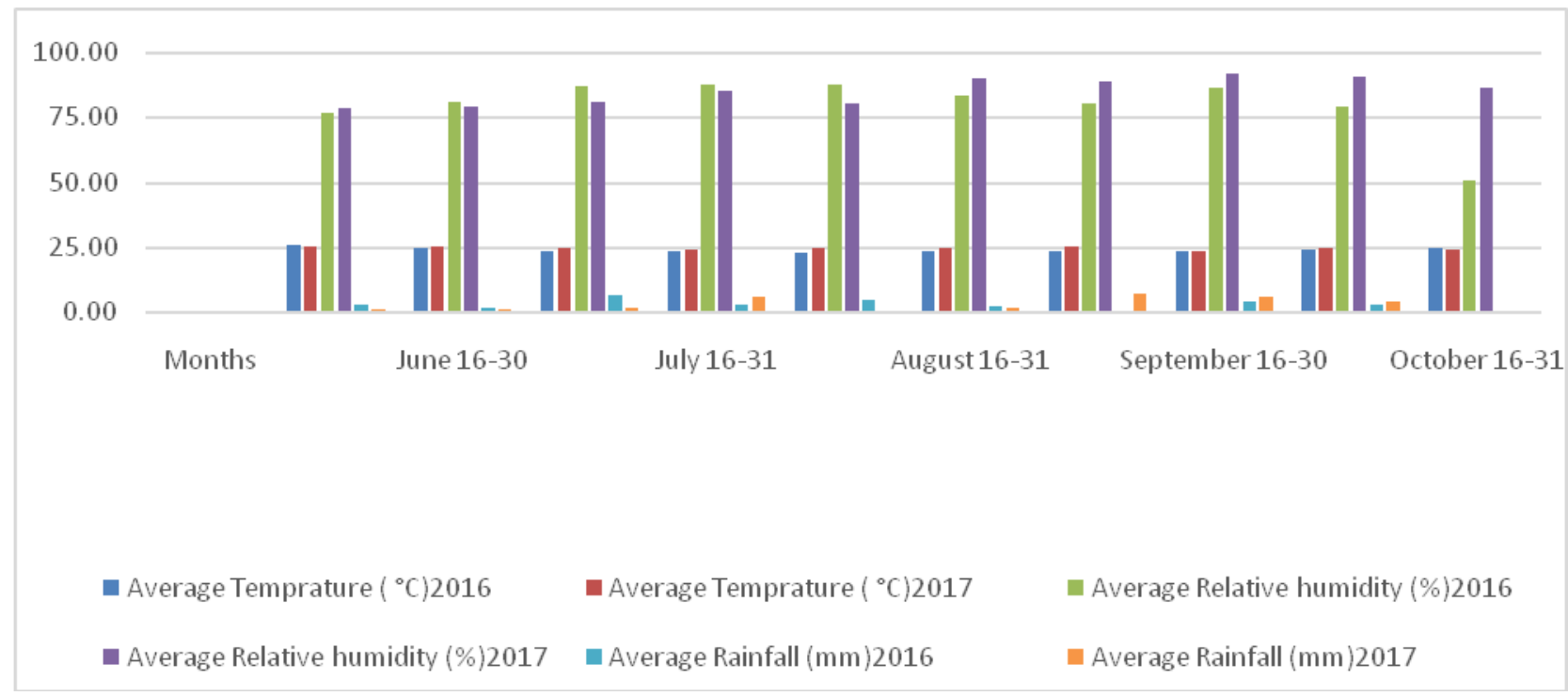

The leaf area duration showed non significant differences due to interaction of date of sowing and foliar application of nutrients at all stages of observation.

Based on the results obtained from the experiment it could be concluded that with delayed sowing, crop growth and seed yield of soybean were adversely affected. Small fluctuations in the weather (temperature) showed higher variations in plant growth and development, which finally influenced on the crop growth and yield of soybean.

Considering the changes in plant growth and yield, first fortnight of June sowing sprayed with $\mathrm{KNO}_{3} @ 0.5 \%+\mathrm{KH}_{2} \mathrm{PO}_{4} @ 0.5 \%+$ Boron 0.50\% and also 19:19:19 @ 3\%+ Boron@0.50\% recorded higher dry matter production, shoot, leaves and pods, crop growth rate and leaf area duration.

\section{References}

Aastha and Janardan, S.,2016. Effect of genotype, sowing schedule and row spacing on growth indices of soybean (Glycine max) under mid hill conditions of Himachal Pradesh. Himachal Journal of Agricultural Research. 42 (2): 131136.

Alexandrov, V. A. and Hoogenboom, G., 2001. Climate variation and crop production in Georgia, USA during the twentieth century. Climate Research. 17(1): 33-43.

Anbumani, S., Chandrasekhran, B., Rajendran, P. and Velayutham, K., 2003. Studies on nitrogen management in greengram. Legume Research, 26 (1):51-53.

Anonymous., 2017. USDA, Foreign Agricultural Services, Washington, DC.

Bastidas, A. M., Setryono, T. D., Dobermann, A., Cassman, K. G., Elmore, R. W., Graef, G. L. and Specht, J. E., 2008. Soybean sowing date: The vegetative, reproductive and agronomic impacts. Crop Science. 48: 727-740.

Daroish, M., Hassan, Z. and Ahad, M., 2005. Influence of planting dates and plant densities on photosynthesis capacity, grain and biological yield of soybean [Glycine max (L.) Merril] Karanj Iran Journal of Agronomy. 4 (3):230-237.

Dhingra, K. K., Kaur, H., Dhaliwal, L. K. and 
Singh, J., 1995. Phenological behaviour and leaf unit requirement of soybean genotypes under different dates of sowing. Journal of Research. Punjab Agric. Univ., 32: 129-135.

Ebrahimi, M., Pouryousef, M., Rastgoo, M. and Saba, J., 2012. Effect of sowing date, plant density and weeds in soybean growth indices. Journal of Plant Protection. 26 (2): 178-190.

Heidarian, A. R., Kord, H., Khodadad. M., Amir, P. and Faezeh, A. M., 2011. Investigating $\mathrm{Fe}$ and $\mathrm{Zn}$ foliar application on yield and its components of soybean [Glycine $\max (\mathrm{L}$.$) Merrill] at$ different growth stages. Journal of Agricultural Biotechnology. Sustainable Development. 3 (9): 189 -197.

Hemantarajan, A., Trivedi, A. K. and Maniram, 2000. Effect of foliar applied boron and soil applied iron and sulphur on growth and yield of soybean [Glycine $\max$ (L.) Merrill] Indian Journal of Plant Physiology. 5(2): 142144.

Jayabal, A., Revathy, M. and Saxena, M. G., 1999. Effect of foliar nutrition on nutrient uptake pattern in soybean. Andhra Agricultural Journal. 46: 243244.

Kalyani, R. R., Devi, V., Satyanarayana, N. V. and Rao. K. V., 1993. Effect of foliar application of boron on crop growth and yield of pigeonpea [Cajanus cajan (L.) Millspaugh]. Indian Journal of Plant Physiology. 36 (4): 223-226.

Kandil, A. A., Sharief, A. E and Sheteiwy, M. S., 2013. Effect of seed storage periods, conditions and materials on germination of some soybean seed cultivars. American Journal of Experimental Agriculture. 3(4): 1020-1043.

Mahmoud, M., Abdalla., Fouad El-Sayed., Abou El-Nour., El-Zanaty Abdel Mottaleb Aly., El-Saady and Abdel K. M., 2006. Boron/Nitrogen interaction effect on growth and yield of fababean plants grown under sandy soil conditions. International Journal of Agricultural research. 1 (4): 322-330.

Mahobia, R. K., Sanjeev, M. and Shrivastava, G. K., 2006. Effect of foliar application of nutrients on growth and yield of pigeon pea under rainfed condition in vertisols of Chattisgarh plains. Annals of Plant Physiology. 20 (2): 215-219.

Neenu, S. K., Ramesh, S., Ramana. and Somasundaram, J., 2017. Dry matter partitioning and yield of different varieties of soybean [Glycine $\max (\mathrm{L}$. Merrill] under aberrant climatic conditions in central India. International Journal of Plant Soil Science. 14 (6):19.

Park, S., Kim, W. and Seong, R., 1987. Influences of different planting times on harvest index and yield determination factors in soybean. Korean Journal of Crop Science. 45(2): 97-102

Potdar, M. V. and Asmotoddin, M., 1991. Effect of sowing dates on yield and yield components of soybean cultivars. Journal of Maharashtra Agricultural Universities. 16: 421-422.

Pradeep, M. D. and Elamathi, S., 2007. Effect of foliar application of DAP, micronutrients and NAA on growth and yield of greengram (VignaradiataL.). Legume Research. 30(4):305-307.

Rajesh, N., 2011, Studies on the performance of transplanting and foliar nutrition in redgram M. Sc. (Agri.), Thesis, Tamil Nadu Agric. Univ., Coimbatore (India).

Reddy, P. K., Narasimha, Rao, C.L. and Mahalakshmi, B. K., 2004. Effect of different chemicals on growth, yield and yield attributes of pigeonpea in Vertisol. Annals of Plant Physiology. 17(2):120124.

Sunil, K. P., Bahuguna, R. N., Madan, P., Trivedi, A. K., Hemantaranjan, A. and Srivastava, J.P., 2010. Effects of 
pretreatment and foliar application of Zinc on growth and yield components of mungbean (Vigna radiate L.) under induced sality. Indian Journal of Plant Physiology. 15 (2): 164-167.

Thalooth, A. T., Tawfik, M. M., Magda. and Mohamed, H., 2006. A comparative study on the effect of foliar application of zinc, potassium, magnesium on growth, yield and some chemical constituents of mungbean plants grown under water stress conditions. World Journal of Agricultural Sciences. 2 (1):37-46.

Vekaria, G. B., Taplada, M. M., Sutaria, G. S, and Akbari, K. N., 2013. Effect of foliar application of potassium nitrate on the growth and yield of greengram (Vigna radiata L.). Legume Research., 36(2): 162-164.

Vibhute, C. P., 1998. A process for manufacturing complex solid and liquid completely water soluble fertilizer. Fertiliser News. 43(8): 63-69.

Zayed, B. A., Salem, A. and Sharkawy, H. M., 2011. Effect of different micronutrient treatments on rice (Oryza sativa L.) growth and yield under saline soil conditions. World Journal of Agricultural Sciences. 7 (2): 179-184.

\section{How to cite this article:}

Sumalatha, G.M. and Uppar, D.S. 2019. Influence of Date of Sowing and Foliar Application of Nutrients on Dry Matter Production, Partitioning and Growth Parameters of Soybean. Int.J.Curr.Microbiol.App.Sci. 8(02): 619-635. doi: https://doi.org/10.20546/ijcmas.2019.802.071 